\title{
Automated Applications of Acoustics for Stored Product Insect Detection, Monitoring, and Management
}

\author{
Richard Mankin ${ }^{1, *(\mathbb{C})}$, David Hagstrum ${ }^{2}$, Min Guo $^{3}$, Panagiotis Eliopoulos ${ }^{4}\left(\mathbb{D}\right.$ and Anastasia Njoroge ${ }^{5}$ \\ 1 United States Department of Agriculture, Agricultural Research Service Center for Medical, Agricultural and \\ Veterinary Entomology (CMAVE), Gainesville, FL 32608, USA \\ 2 Department of Entomology, Kansas State University, Manhattan, KS 66502, USA; hgstr@ksu.edu \\ 3 School of Computer Science, Shaanxi Normal University, Xi'an 710119, China; guomin@snnu.edu.cn \\ 4 Department of Agrotechnology, University of Thessaly, 41500 Larissa, Greece; eliopoulos@uth.gr \\ 5 Tropical Research and Education Center, Institute of Food and Agricultural Sciences, University of Florida, \\ Homestead, FL 33031, USA; anjoroge@ufl.edu \\ * Correspondence: Richard.Mankin@usda.gov; Tel.: +1-352-374-5774
}

check for updates

Citation: Mankin, R.; Hagstrum, D.; Guo, M.; Eliopoulos, P.; Njoroge, A. Automated Applications of Acoustics for Stored Product Insect Detection, Monitoring, and Management. Insects 2021, 12, 259. http://doi.org/ $10.3390 /$ insects 12030259

Academic Editor: George N. Mbata

Received: 19 February 2021

Accepted: 5 March 2021

Published: 19 March 2021

Publisher's Note: MDPI stays neutral with regard to jurisdictional claims in published maps and institutional affiliations.

Copyright: (c) 2021 by the authors. Licensee MDPI, Basel, Switzerland. This article is an open access article distributed under the terms and conditions of the Creative Commons Attribution (CC BY) license (https:// creativecommons.org/licenses/by/ $4.0 /)$.
Simple Summary: A variety of different acoustic devices has been commercialized for detection of hidden insect infestations in stored products, trees, and soil, including a recently introduced device demonstrated in this report to successfully detect rice weevil immatures and adults in grain. Several of the systems have incorporated digital signal processing and statistical analyses such as neural networks and machine learning to distinguish targeted pests from each other and from background noise, enabling automated monitoring of the abundance and distribution of pest insects in stored products, and potentially reducing the need for chemical control. Current and previously available devices are reviewed in the context of the extensive research in stored product insect acoustic detection since 2011. It is expected that further development of acoustic technology for detection and management of stored product insect pests will continue, facilitating automation and decreasing detection and management costs.

Abstract: Acoustic technology provides information difficult to obtain about stored insect behavior, physiology, abundance, and distribution. For example, acoustic detection of immature insects feeding hidden within grain is helpful for accurate monitoring because they can be more abundant than adults and be present in samples without adults. Modern engineering and acoustics have been incorporated into decision support systems for stored product insect management, but with somewhat limited use due to device costs and the skills needed to interpret the data collected. However, inexpensive modern tools may facilitate further incorporation of acoustic technology into the mainstream of pest management and precision agriculture. One such system was tested herein to describe Sitophilus oryzae (Coleoptera: Curculionidae) adult and larval movement and feeding in stored grain. Development of improved methods to identify sounds of targeted pest insects, distinguishing them from each other and from background noise, is an active area of current research. The most powerful of the new methods may be machine learning. The methods have different strengths and weaknesses depending on the types of background noise and the signal characteristic of target insect sounds. It is likely that they will facilitate automation of detection and decrease costs of managing stored product insects in the future.

Keywords: Sitophilus oryzae; Tribolium castaneum; abundance; population density; neural networks; machine learning

\section{Introduction}

Acoustic technology has a long history of supporting insect pest managers with decision tools and providing contextual information on insect life history, feeding, and movement [1-9]. Similar technology is being applied in other areas of agriculture, such as 
the analysis of cattle behaviors $[10,11]$. As shown in different sections and tables below, the fundamental and practical utility of acoustic technology has increased over time, due partly to decreases in the costs of sensors and signal recording systems, large increases in signal processing speeds and data storage capability, and rapid expansion in methods to identify sound patterns of targeted insects and discriminate them from background noise. The use of acoustic technology in insect pest management applications increased rapidly between 1980 and 2010 [2] and likely will continue, as global trade and incidental transport of invasive species continue to expand [12,13], heightening the needs for improved detection and monitoring of insects in stored product commodities. The 2011 report [2] covered 137 papers on insect acoustic detection published over more than a century, and this report adds considerably to the total, focusing on the decade since 2010 but including also several relevant papers from previous decades that had not been included in the 2011 report (Table 1).

Table 1. Increases over decades in reports describing insect acoustic detection applications.

\begin{tabular}{ccc}
\hline Decade & \multicolumn{2}{c}{ No. Papers Listed } \\
\hline $1901-1910$ & Herein & Mankin et al. [2] \\
$1911-1920$ & & 1 \\
$1921-1930$ & & 1 \\
$1930-1940$ & & 2 \\
$1941-1950$ & & 4 \\
$1951-1960$ & & 0 \\
$1961-1970$ & 1 & 5 \\
$1971-1980$ & 2 & 4 \\
$1981-1990$ & 6 & 4 \\
$1991-2000$ & 14 & 22 \\
$2001-2010$ & 46 & 44 \\
$2011-2020$ & 133 & 50 \\
Total & 202 & 137 \\
\hline
\end{tabular}

Table 2 lists applications where acoustic technology has provided information on topics of long-term interest both before and after 2010. In brief, insects have been acoustically monitored not only in stored grain, legumes, fresh fruits, and vegetables, but also in agricultural shipments, bamboo, banana trees, bromeliads, citrus groves, cotton bolls, nursery containers, palm tree groves, turf grass, urban trees, vineyards, and museums containing wooden cultural heritage and musical instruments. Mosquitos have been monitored in salt marshes and trapped to monitor populations of public health interest.

Acoustic monitoring is one of the few methods available for detecting and monitoring the development of hidden larvae feeding internally in stored products, enabling noninvasive documentation of timing when the larvae cease feeding during the molt from one instar to the next (see Section 1.2). Monitoring of feeding reduction and cessation also has been useful in evaluating effectiveness of entomopathogens, host plant resistance, hermetic storage, and insecticides. Insect monitoring studies in Table 2 range from simulated to large scale field tests, and from manual to automated data collection and analysis. Grain damage has been detected in maize, rice, and wheat using impact acoustics. Acoustic trapping of insects also has been used as a monitoring tool. However, the number of studies on detection of infestations is considerably larger than those using acoustics to measure infestation density, possibly because a typically large standard deviation in the rates of sounds produced per insect requires large numbers of samples per study for precise estimations, especially with insects of small size [14-19].

The numbers of insect acoustic detection and monitoring studies have greatly increased since 2010 (Table 1) but only a small fraction has dealt with stored product insects. The number of studies on wood borers is nearly as many as with pests in all other studies combined. For the 134 studies cited in Table 2 the average of 6.0 papers per year during the 
last 10 years is higher than the average for earlier studies from 1988 to 2010 of 3.3 papers per year. Evidently, an overall increased effort to improve acoustic insect detection technology and practical utility has yielded increased interest not only for management of insects in stored products but also for management of insects in other hidden substrates, including trees, interior structures of plants, and underground.

Table 2. Examples of different early and recent insect acoustic detection applications.

\begin{tabular}{ccc}
\hline Research Application & References before 2011 & References since 2011 \\
\hline Monitor biology on: & & \\
Feeding, mobility, alarm behavior & {$[20-32]$} & {$[33-35]$} \\
Avoidance of oviposition competition in seeds & {$[36]$} & {$[37]$} \\
Life history & {$[24,38]$} & {$[39]$} \\
Seasonal/daily feeding rates & {$[41-46]$} & {$[40]$} \\
Humidity effects on activity/feeding & {$[49,50]$} & {$[47,48]$} \\
Temperature effects on activity & {$[46,58,59]$} & {$[60]$} \\
Temperature preference & & {$[62-64]$} \\
Detection/monitoring of: & {$[61]$} & {$[70-75]$} \\
Damaged stored food & {$[49,65-69]$} & {$[94-107]$} \\
Stored product insects & {$[14,76-93]$} & {$[4,120-124]$} \\
Wood boring insects & {$[108-119]$} & {$[16,17,130-132]$} \\
Soil-dwelling \& other insects & {$[125-129]$} & \\
Biosecurity and insect density monitoring & & {$[133,134]$} \\
\hline Monitoring efficacy of: & {$[31,135]$} & {$[137]$} \\
Entomopathogens & {$[136]$} & {$[18,74,138]$} \\
Host-plant resistance & {$[141-143]$} \\
Heat treatment & {$[136,139,140]$} & {$[149-152]$} \\
\hline Insecticide/fumigations & {$[144-148]$} & \\
\hline Trapping of insects to monitor populations & &
\end{tabular}

\subsection{Improvements over Time in Discrimination/Identification of Insect Sounds}

One of the most active areas of insect acoustic detection research is the development of improved methods to identify the sounds of targeted insect species and distinguish them from background noise. Some of these methods are physical, e.g., reduction of background noise by acoustically insulating the samples when feasible $([153,154])$. Others involve a variety of feature identification and classification analyses for processing of signals of different characteristics. Table 3 lists some of the most important of the signal preprocessing, feature extraction, and pest identification/discrimination (classification) analyses (e.g., Sharan and Moir [155]) that have been introduced and tested to develop information about pest insect acoustic activity, as well as different statistical methods that have been adapted to distinguish sounds produced by different insect species and different behavioral activities of individual species from each other. The process of feature extraction is termed mathematically as convolution [156]. The automated signal recognition methods in Table 3, (a)-(e) are subdivided into broad categories as follows:

(a) Signal preprocessing. This often includes band-pass filtering of the amplified analog recordings, typically focusing on a frequency band between 80 and $8000 \mathrm{~Hz}$ to capture the brief, 3-30 ms impulses produced by insect movement and feeding [2]. The waveform amplitude is a commonly determined signal feature. Many analyses set a threshold visually or statistically and discard signal segments from further analysis if they do not contain above-threshold magnitudes. A commonly applied classification method counts the rate of occurrence of signal segments exceeding the threshold and then classifies stored product samples as infested if the rate exceeds an experimentally determined minimum value. More complex analyses make use of additional signal features such as the total energy or the temporal envelope of short tones or bursts of pulses [157]. Other classification methods employ multiple sensors. Wireless networks employ groups of sensors, spaced either closely together to determine locations of insects in stored grain based on the timing of 
detection of signal pulses [158], or further apart to estimate widespread populations within a large quantity of stored grain [159] or within multiple trees in an urban area [160].

(b) Neural network classifiers. Artificial neural networks (ANN) are computer models of brain neuron linkage processes that combine weighted inputs from observational data, e.g., acoustic signal pulses, and produce a single binary output that learns its correct value from the observational inputs by use of backpropagation or other methods [161]. Machine learning incorporates neural networks, including convolutional neural networks (CNN) [162], and probabilistic neural networks (PNN), perceptual learning prediction (PLP), decision trees and forests, hidden Markov models (HMM), support vector machines (SVM), Bayesian classifiers, and other methods to improve its predictions automatically through experience with datasets where the target insect species have been independently identified [163-165]. Deep learning [156] is a machine learning method that incorporates multiple layers of neural networks, each of which extracts specific features or learned representations of input data [164].

(c) Spectral and temporal pattern features. Specific features of the acoustic signal have been demonstrated to have good predictive value for identifying insects sounds and discriminating them from background noise. Analyses that extract such features include temporal (time domain) pattern identification, spectral, wavelet, and formant analyses, as well as Independent Component Analysis (ICA). In several investigations, acoustic indicators have been constructed that combine information from multiple acoustic features $[166,167]$ or combinations of features from multiple types of sensors $[114,168]$ that provide standardized comparative information useful for targeting insect populations or for monitoring changes in insect and other animal populations in protected areas.

(d) Gaussian Mixture Model (GMM) and Vector Quantization (VQ). These clustering algorithms also are applied to distinguish between features of target signals and background noises [91,169].

(e) Classification algorithms. Subband-based Cepstral Coefficients (SBC) [170], Linear Predictive Cepstral Coefficients (LPCCs) and Mel-Frequency Cepstral Coefficients (MFCCs) [171], as well as wavelets [172,173], KNeighbors [16] classifiers and similar Medium and Complex tree classifications [165] have been used also to distinguish target signals from other signals.

Modern classification methods have different strengths and weaknesses depending on the types of background noises and the characteristics of the insect sounds. Machine learning, including deep learning [174], ultimately may be the most powerful of these methods, provided there is enough training data. The training of convolutional neural networks may require fewer training samples than for deep learning [175]. Similar methods are also becoming widely used in other areas of agriculture [176]. Given initial uncertainty about which classification method to use, researchers may find it most beneficial to begin by first identifying a pivotal question, collecting ground-truth data in relevant environmental contexts, and then testing the success of multiple classification methods before making a final decision about the best signal processing methods to employ.

Table 3. Examples of automated signal recognition and classification activities subdivided according to approximate order of first usage with insects (Methods abbreviations are defined in the text).

\begin{tabular}{lc}
\hline \multicolumn{1}{c}{ Method } & References \\
\hline (a) Signal preprocessing, feature extraction, & {$[125,177-185]$} \\
Multiple sensors, wireless networks & {$[129,159,160,163,165,171,186-189]$} \\
(b) neural network classifiers: ANN, machine learning, deep learning, & {$[16,48,123,130,162,163,165,171,175,190-196]$} \\
CNN, HMM, SVM, PLP, PNN & {$[2,68,87,99-101,106,107,197-207]$} \\
(c) Spectral and temporal pattern features, formant and wavelet analyses & {$[48,85,207-209]$} \\
Time domain signal features, ICA & {$[6,168,205,210]$} \\
Polymodal sensor systems, acoustic indicators & {$[91,120,211-214]$} \\
(d) GMM, VQ, denoising, fine gaussian SVM & {$[16,55,56,165,171,213-220]$} \\
(e) SBC, LPCC, and MFCC analysis, KNeighbors classification & \\
\hline
\end{tabular}




\subsection{Advantages of Hidden Immature Insect Detection for Stored Grain Pest Management Decisions}

Acoustic technology is particularly valuable for assessing hidden larval infestations in stored grain. Grain samples often have both adult and immature stages of insect pests. Immatures hidden inside the grain kernels are more difficult to separate from grain and identify than adults. The traditional method of detecting immatures is to incubate the grain samples. The incubation time can extend up to two months [221]. To reduce this delay, indirect methods have been proposed based on the determination of obvious indicators of insect presence or activity (mainly focused on advanced larval stages): respiratory gas release, X-ray radiography, flotation, and ninhydrin colorimetric methods [221], as well as acoustic indices of detection $[114,166]$.

Immature insects are often more abundant than adults in seed storages and may be present in samples in which no adults are found. For example, the ratios of immatures to adults in farmer deliveries of wheat to central stores in Australia were estimated at 2.2 for 1962. 4.4 for $1964,1.1$ for 1975, 3.6 for 1977, and 4.4 for 1978 [222]. When the egg stage was omitted because of the difficulty of sampling, X-ray monitoring revealed that larvae, pupae, and adults of Rhyzopertha dominica (F.) (Coleoptera Bostrichidae) were 80.6, 10.4, and 9.0\% of the population, respectively [126]. These estimates did not differ significantly among samples taken during the 6th, 8 th, and 10 th week of the study. The 9 -fold difference in densities between adult and larval stages was small compared with the 37-fold difference in the number of sounds they produced. In another study that compared ratios of immatures to adults, mean immature to adult ratios were $488.5,85.9,71.8,56.6,55.8,17.8,11.2,9.7,5.5$, $5.2,4.4,3.0,1.9$ in wheat samples from a grain elevator bin [223]. Thirteen locations had immatures but no adults.

In a study of insect infestations in railcars carrying grain, adult $R$. dominica were found in two of eight railcars sampled and represented only $2 \%$ of the total lesser grain borer population; whereas, immature $R$. dominica were present in five of the sampled railcars and represented $98 \%$ of the total $R$. dominica population [224]. Adult and immature Cryptolestes. ferrugineus Stephens (Coleoptera: Laemophloeidae) were found in four railcars and represented 5 and 95\% of the C. ferrugineus beetle population, respectively [224]. For a growing population, adults represent the previous generations, immature stages are the next generation of adults and the population growth rate will determine immature to adult ratio. Long-lived adults may survive for several generations reducing the immature to adult ratio.

\section{Materials and Methods}

\subsection{New Technologies since 2011}

In the early days of insect acoustic detection research, investigators often had to devise their own sensor systems or modify devices intended for general acoustics [2]. As the field has matured, however, multiple devices have been commercialized to detect insects in stored products, trees, and soil. Table 4 lists several devices with sensors that have been suitable for use with stored product insects, some of which are still in production.

Table 4. Recently developed sensor systems applicable to pest insect detection in stored products.

\begin{tabular}{ccc}
\hline Sensor Label $\mathbf{1}^{\mathbf{~} \text { (Name) }}$ & Device Source & Reference(s) \\
\hline ec (elec. conduct. sens.) & Research laboratory & {$[7,225]$} \\
ia (impact acoustic) & Research laboratory & {$[5,61,63,64,226]$} \\
lv (laser vibrometer) & Polytec, Berlin, DE & {$[227]$} \\
m (digital stethoscope) & {$[228]$} & {$[149]$} \\
m (insect tap) & 3M Littmann, Maplewood, MN & {$[229]$} \\
m (red palm weevil detector) & Research laboratory & {$[230]$} \\
mem (micrelectromech.) & Research laboratory & {$[231,232]$} \\
o (distributed optical fiber, or reflected light) & Research laboratory & {$[233,234]$} \\
o (salient edge detection) & Research laboratory & {$[49]$} \\
p (EWD) & Research laboratory & Research laboratory \\
\hline
\end{tabular}


Table 4. Cont.

\begin{tabular}{ccc}
\hline Sensor Label $^{\mathbf{1}}$ (Name) & Device Source & Reference(s) \\
\hline p (AED 2010L, R15a) & AEC Inc., Fair Oaks, CA, Physical & {$[15,18,34,71,74,75,102,138,235-237]$} \\
pa (TreeVibes) and related & Acoustics, Princeton, NJ & {$[17,130,160,238,239]$} \\
pa (Postharvest insect Detection System) (PDS) & Insectronics, Chania, Crete, Greece & {$[19]$} \\
pa & Cust. Eng. Sol, West Hempstead, NY & {$[240]$} \\
pa (Integr. Circuit Piezo) & Bosh Sensortech, Reutlingen, GM & {$[92,106,241]$} \\
pa (electroacoustic sens.) & Research laboratory & {$[242]$} \\
pu (Purdue Biomon.) & Research laboratory & {$[24,33,135]$} \\
pu (focused transducer) & Research laboratory & {$[243]$} \\
pvdf (polyvinylidene fluoride) & Ultran Labs, Boalsburg, PA & {$[47]$} \\
rm (microwave radar) & Piezo \& Pyro PVDF \& PVDF-TrFE, State & {$[56,244,245]$} \\
rm (microwave radar) & Coll, PA & {$[246]$} \\
pcr (polymerase chain reaction) & Termatrac, Ormeau, QLD, Australia & {$[247]$} \\
ss (seismic sensor) & Research laboratory & {$[9]$} \\
st (sonic tomography) & Biotools, Madrid Spain & {$[101,248]$}
\end{tabular}

${ }^{1} \mathrm{ec}=$ electrical conduction, ia = impact acoustic, $\mathrm{lv}=$ laser vibrometer, $\mathrm{m}=$ microphone, mems = microelectromechanical sensor, $\mathrm{o}=$ optical fiber or reflected light, $\mathrm{p}=$ contact pickup using PZT piezoelectric transducer, $\mathrm{pa}=\mathrm{PZT}$ accelerometer $(0-20 \mathrm{kHz})$, pu $=\mathrm{PZT}$ ultrasonic transducer $(20-200 \mathrm{kHz})$, pvdf = polyvinylidene fluoride film, rm = resonant microwave radar, ss = seismic sensor, st = sonic tomography.

In subsections below, we consider some of the recent activities in different world areas where local problems have influenced the focus of pest management and parts of the research may have been written in languages other than English.

\subsection{Methods Development and Application in Europe}

Only a few acoustic systems have been evaluated for insect detection in storage facilities in Europe during the last decade. A commonly used and well-studied system has been AED 2010L (Acoust. Emiss. Consult., Fair Oaks, CA, USA), a portable, battery-operated system including a piezoelectric sensor mounted on the end of a metal probe pushed into the grain and a portable acoustic emission amplifier. It has been recently examined in Greece [15-17,131,250] and has demonstrated noteworthy efficiency in detecting insect presence inside the grain mass, even in the "critical" density of one or two adult beetles per Kg grain, for a plethora of grain pests such as Acanthoscelides obtectus (Say) (Coleoptera: Chrysomelidae) and Callosobruchus maculatus (F.) (Coleoptera: Chrysomelidae) [17,131], Sitophilus oryzae (L.) (Coleoptera: Curculionidae), $R$. dominica, Tribolium confusum Jacquelin du Val (Coleoptera: Tenebrionidae), Oryzaephilus surinamensis (L.) (Coleoptera: Silvanidae), Trogoderma granarium Everts (Coleoptera: Dermestidae), C. ferrugineus, Lasioderma serricorne (F.) (Coleoptera: Ptinidae), Ephestia kuehniella Zeller (Lepidoptera: Pyralidae), and Plodia interpunctella Hübner (Lepidoptera: Pyralidae) [15,16,131,250]. The same system was also successful, under certain conditions, in detecting infestations by dry-woodboring insects like Hylotrupes bajulus (L.) (Coleoptera: Cerambycidae), Anobium punctatum De Geer (Coleoptera: Ptinidae), Xestobium rufovillosum (De Geer) (Coleoptera: Ptinidae), and Lyctus sp. (Coleoptera: Bostrichidae) [105] (Table 2).

A different system has been developed and evaluated in Germany, where highly sensitive microphones installed in a metal tube were inserted in the grain mass. The tube not only provided protection for the highly sensitive equipment from dust and other forces but also had acoustical advantages, increasing the surface on which beetle signals could be detected. Additionally, the tube worked as a beetle trap recording all sounds from even one single beetle inside the trap. In lab conditions the infestation could be detected about 8 weeks before a temperature rise, or beetles at the grain surface indicated an infestation [149] (Table 4).

Apart from stored grain pests, bioacoustic methods also have been applied for detection of other cryptic wood-boring insects [97,121,160,239]. For example, detection of the 
red palm weevil (RPW), Rhynchophorus ferrugineus Olivier (Coleoptera: Dryophthoridae), a major pest of various palm species, has been achieved in Israel by a piezoelectric sensor inserted in the fibrous palm tissue. The method was efficient for detecting grown larvae or adults (75-95\% sensitivity) but was not successful during the early phase of infestation (33-39\% sensitivity) [98]. Similarly, internal larval infestation of banana weevil Cosmopolites sordidus (Germar) (Coleoptera: Curculionidae) was acoustically detected (90\% accuracy) with a simple sensor (diaphragm stethoscope) connected to a filter to separate the signal from background noises [121].

Acoustic detection methods evaluated in detecting xylophagous insects are very similar to those applied in storage facilities. Acoustic emissions produced by very small wood-boring larvae (1-2 $\mathrm{mm}$ length) in wooden objects were measured with piezo-electric sensor and two amplifiers [97]. A novel system called TreeVibes has been recently developed for the automated, real-time, and continuous detection of woodborers inside trees $[160,239]$. The main parts of the device are an accelerometer and an electronic board that transduces vibrations into audio signals that are stored, compressed and wirelessly transmitted. The TreeVibes demonstrated $\sim 90 \%$ detection accuracy in the cases of Xylotrechus chinensis (Chevrolat) (Cerambycidae) and R. ferrugineus. Many other applications have been suggested for this device, including pest detection in grain silos [160] and grain samples (Section 2.4).

\subsection{Methods Development and Application in Asia}

Initial studies of stored product insect acoustic detection in Asia focused on developing a basic understanding of the magnitude and frequencies of insect-produced signals. Guo and Shang [197,251,252], for example, conducted studies of Tribolium castaneum (Herbst) and O. surinamensis crawling on film over a microphone. Matlab software (MathWorks, Natick, MA) was used to distinguish the amplitude and frequency of the signals. In a series of reports, Geng, Shang, Bai, Li, and Zhao conducted exploratory studies of crawling sounds detected by microphone from T. castaneum adults in wheat, soybean, and corn, and crawling sounds produced in wheat by adults of $S$. oryzae and black fungus beetle, Alphitobius diaperinus Panzer (Coleoptera: Tenebrionidae) [154,181,202,204,251-253]. Sound spectra of the same species were different in different grains, and the spectra of sounds produced by immatures were different from those of adults. The tests were conducted in an acoustically insulated chamber to reduce extraneous noise. To expand detection to a wider area, Han et al. [159] developed a stored product insect sound detection system connected to a wireless sensor network. Because the ZigBee (Zigbee, Davis, CA, USA) wireless communication system had limited bandwidth, data compression, transmission, and recovery systems were included in the software. Several reviews have been conducted that focused on research progress associated with stored product insect detection technology, including [254-264].

A major focus of stored product insect acoustic detection research in Asia has been in development of methods to discriminate pest insect signals from background noise and other, nontargeted insects. An early approach was work by Guo and Zhang [213] that identified movement sounds of S. zeamais (Motschulsky) (Coleoptera: Curculionidae) and T. castaneum adults using Mel Frequency Cepstrum coefficients, Gaussian Mixture Models, and clustering. Zhang et al. [172] used wavelet analyses to distinguish S. oryzae larvae from S. zeamais in wheat, maize and Coix lacryma-jobi (Poales Poaceae) millet. The sounds of the stored grain insects depended on the grain size and temperature [265].

Other studies in Asia and Europe have considered physical factors affecting insect acoustic detectability such as the speed of sound and signal attenuation in grain. Guo, Geng, $\mathrm{Li}, \mathrm{Yu}$, and others [183,198,265-269] conducted studies to estimate times of sound travel in grain and signal attenuation in grain. These factors also are affected by temperature and moisture [270-273]. 


\subsection{Methods Development and Application in Africa and the Americas}

As in Europe (see Section 2.2), the AED 2010L system has been used in Kenya and the US to detect stored product insects in several studies since 2012. Acoustic methods provide early warning of hidden insect presence before devastating infestation thresholds are reached. However, stored product insect infestations in African farmer stores or large grain warehouses are mainly controlled by fumigation and contact insecticide applications, as the usage of detection and monitoring tools is still in the early stages of development [236]. Studies were conducted between 2014 and 2017 in Kenya to assist the development of acoustic sensors for monitoring infestations in food grain warehouses $[18,75,236,237]$. The research involved lab- and field-based approaches using the AED-2010L (Table 4) as well as older condenser microphone technologies to determine detection capabilities and assemble acoustic profiles [2] of sounds produced by immature and adult stored grain insects, with and without interference from background noise. Acoustic profiles were created for Prostephanus truncatus, Horn) (Coleoptera: Bostrichidae), S. zeamais (Motschulsky) (Coleoptera: Curculionidae) and T. castaneum in maize and A. obtectus in beans. The profile ranges of greatest spectral energy were established to be between $3-8 \mathrm{kHz}$. Acoustic data combined with pit-fall trap-capture data and background noise collected under field conditions in large grain storage facilities provides sufficient information to develop automated decision-support tools [237].

Acoustic detection was also explored for application among organic grain growers in the United States. The project goal was to help organic growers in the US Midwest seeking chemical-free pest management tools for specialty crop storage. Research was conducted in Indiana between 2017 to 2019 on the use of acoustic detection methods as a monitoring tool during hermetic and controlled atmosphere storage of cowpea and wheat $[18,75,138]$. Laboratory experiments were performed to assess the effect of low oxygen environments on the insect behavior, life cycle, fecundity, susceptibility and resurgence of $S$. oryzae on wheat and C. maculatus on cowpea. Low oxygen levels were attained by hermetic sealing of infested grain or purging of infested grain with $\mathrm{N}_{2}$. Hermetic sealing reduced the insect acoustic activity below minimum activity threshold levels, $<0.02$ sound bursts/s, within $14 \mathrm{~d}$ while low oxygen levels of $1 \%, 3 \%$, and $5 \%$, ended insect acoustic activity within $4 \mathrm{~d}$. Ultimately, this research seeks to implement an acoustic monitoring system for testing efficacy of $\mathrm{N}_{2}$ (or other gases such as $\mathrm{CO}_{2}$ ) fumigation in grain storage facilities in the Midwest United States.

Besides the AED 2010L, two other acoustic systems have been tested recently in the US to detect stored product insect pests. The Postharvest insect Detection System, PDS, developed by Custom Engineered. Solutions, Inc. (Jeffersonville, Indiana) (Table 4), inputs signals from electret microphones to a 32-bit microcontroller platform that digitizes the sounds and saves them on a memory card for further analyses, enabling discrimination of target insect sounds from background noise and nontarget pest species, as well as population density estimation [19]. The microphones are embedded in a plastic base onto which bags of grain samples are temporarily placed to estimate infestation likelihood.

The capabilities of a second new device, TreeVibes $[160,239]$, were tested for this report. The TreeVibes was connected to a metal probe inserted into three sets of four glass jars, each containing approximately $300 \mathrm{~mL}$ of wheat grains artificially infested with 0 (control)-50 S. oryzae adults, or with larvae from eggs laid by $0-50$ adults in grain over a 1-week period. All insects in the study were reared and maintained as in Mankin et al. [19] and were tested only once. Except for the brief $<1 \mathrm{~h}$ recording periods, the jars were kept in a rearing chamber at $25.1 \pm 1{ }^{\circ} \mathrm{C}$ and $50 \pm 5 \%$ relative humidity. The signals detected by the probes were transmitted from the TreeVibes headphone output to a digital audio recorder (Model PMD661, Marantz, Mahwah, NJ, USA) and saved in ".wav"-file format at a $44.1 \mathrm{kHz}$ digitization rate. To accommodate the limited, $1-8000 \mathrm{~Hz}$ frequency range of the accelerometer [160], the signal was bandpass filtered between $160 \mathrm{~Hz}$ and $8000 \mathrm{~Hz}$, and then displayed using Raven 1.5 software [274]. 


\section{Results}

The TreeVibes device easily detected insect-produced sounds from the 300-mL grain samples infested with either adult or larval S. oryzae. Figure 1 displays a $6.7 \mathrm{~s}$ period of movement and feeding signals obtained from $10 \mathrm{~S}$. oryzae adults that had been placed into a rearing jar filled with wheat grains 6 days previously. The oscillogram (A) displays signal pulses of varying amplitudes spaced in trains (bursts) of varying durations [2]. The spectrogram (B) indicates that the pulses produced by adults typically have their greatest energy between 500 and $1500 \mathrm{~Hz}$, with a few pulses also containing moderate energy between $6-8 \mathrm{kHz}$.

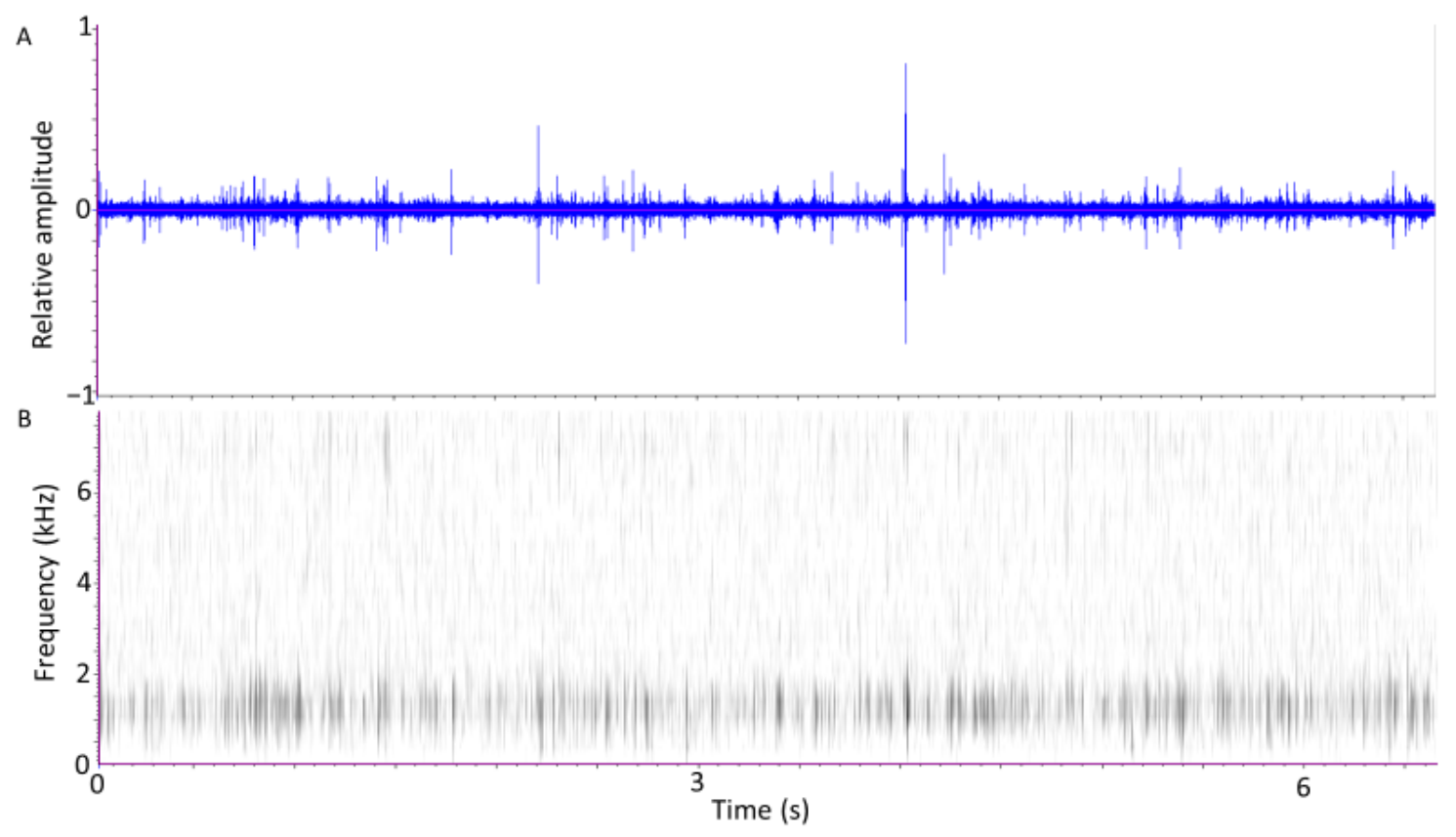

Figure 1. (A) Oscillogram and (B) Spectrogram of a $6.7 \mathrm{~s}$ interval of sounds recorded from 10 adult S. oryzae. Darker areas in the spectrogram (calculated at 128 points/spectrum) indicate greater energy at specific frequencies and times.

Figure 2 displays signals obtained from S. oryzae larvae two weeks after 10 adults had been removed from a jar in which they had been introduced for 1 week. Here, the signals are primarily feeding sounds of the larvae hidden within the kernels. As in Figure 1, the oscillogram (A) displays bursts of pulses of varying amplitudes. The spectrogram (B) indicates that the larval pulses have less energy below $2 \mathrm{kHz}$ than the adults and have the greatest energies between 6 and $8 \mathrm{kHz}$. The total number of larvae was not known in this case but about 300 adults were collected from this test jar over the subsequent three weeks.

Examples of mean spectra (profiles) of adult and larval sound pulses (Figure 3) were obtained using a custom-written insect sound analysis program, DAVIS [2]. For the adult profile, spectra from 1410 pulses obtained over a $180 \mathrm{~s}$ period were averaged from a recording of $10 \mathrm{~S}$. oryzae adults placed into a rearing jar 6 days previously. The larval profile was a spectral average of 84 pulses collected by the TreeVibes sensor over $180 \mathrm{~s}$ in a jar where 10 adults had been introduced three weeks previously and then removed 1 week later. The shape of the adult profile confirmed results from previous analyses of adult $S$. oryzae sound impulses detected using the PDS device [19], and the larval profile confirmed results previously obtained by Kiobia et al. [71] with S. oryzae larvae using an AED 2010L system. In tests with uninfested samples, a few isolated grain-settling sound pulses were detected at rates at or below $0.02 \mathrm{~s}^{-1}$, as had been observed also with the PDS device [19]. 


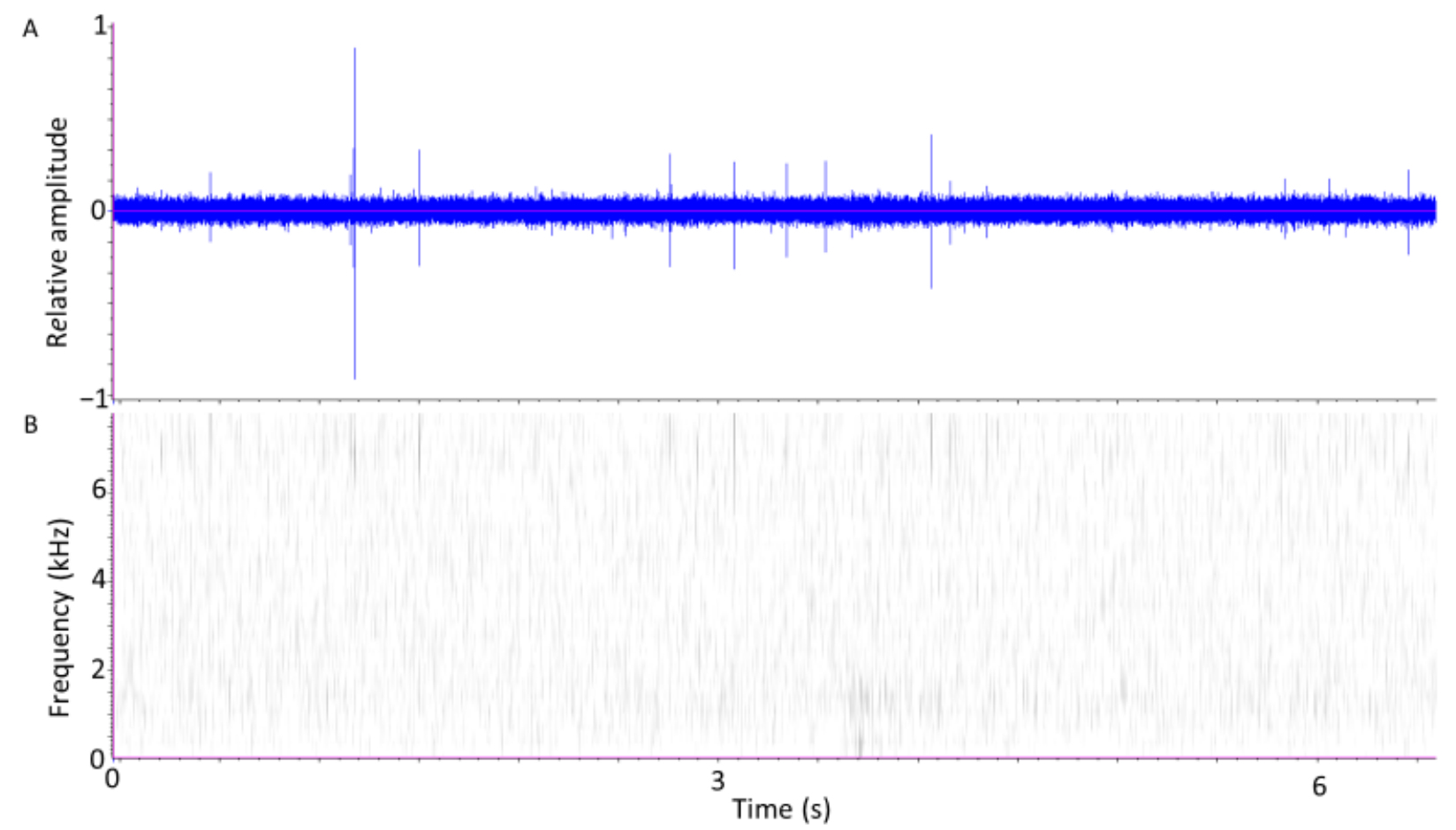

Figure 2. (A) Oscillogram and (B) Spectrogram of a $6.7 \mathrm{~s}$ interval of feeding sounds recorded from S. oryzae larvae. Darker areas in the spectrogram (calculated at 128 points/spectrum) indicate greater energy at specific frequencies and times.

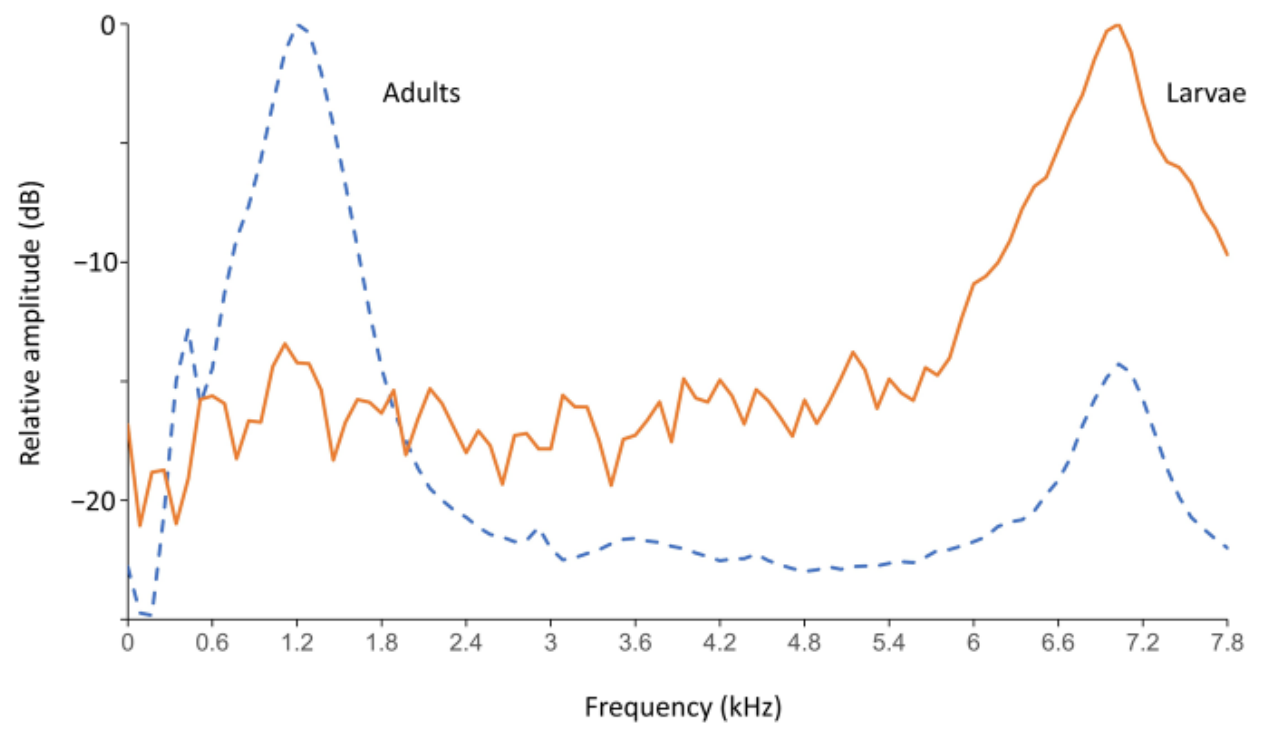

Figure 3. Mean spectral profiles: 10 Sitophilus oryzae adults on grain kernels (dashed line) and larvae figure $180 \mathrm{~s}$ recordings.

\section{Discussion}

The results of the TreeVibes tests with S. oryzae adults and larvae above, as well as those with the PDS device (19), confirm their potential for use in future applications of stored product insect acoustic detection and monitoring. Indeed, as discussed in the subsections below, there is an expanding body of insect acoustic signal detection and analysis studies suggesting that such research will be of growing importance for stored product insect management over the next decade.

It is worthwhile noting that, apart from what has already been described, there are other reviews, research, and theses of relevance to management of stored product insects which do not directly address stored product applications. Such studies include on termites 
and other tree-boring insects that produce feeding sounds that have spectral and temporal patterns like those of stored product insects [94,95,142,143,235]. Others describe effects of temperature on rates of activity [60]. Others incorporate optical sensors in traps [150,275] with similarities to pitfall traps used for monitoring stored product insects [236]. Finally, we note the increased usage of acoustic detection methods against invasive stored product pests, e.g., Trogoderma inclusum LeConte [276] and other invasive Trogoderma spp. [15,277].

A recent search for master and Ph.D. theses investigating insect acoustic detection and monitoring found four M.S. and ten Ph.D. theses, seven of which have been published since 2011, (Table 5). They cover a range of topics, from sound propagation in stored grain, to feeding behavior, sound feature extraction, discrimination of insect sounds from noise, methods development, and the use of wireless to obtain insect sounds from multiple locations in storage facilities.

Table 5. Recent theses on insect acoustic detection and monitoring.

\begin{tabular}{|c|c|c|c|}
\hline Author; Type & Year & University & Title \\
\hline El-Hadad, A.; Ph. D. [101] & 2017 & U. Melbourne & $\begin{array}{l}\text { Using acoustic emission technique with Matlab analysis to detect } \\
\text { termites in timber-in-service }\end{array}$ \\
\hline Farr, I.; Ph.D. [278] & 2007 & Univ. York, U.K. & $\begin{array}{c}\text { Automated bioacoustic identification of statutory quarantined } \\
\text { insect pests }\end{array}$ \\
\hline Geng, S.; Ph.D. [279] & 2005 & $\begin{array}{l}\text { Shaanxi Normal Univ., } \\
\text { China }\end{array}$ & $\begin{array}{l}\text { Sound characteristics detection, analysis and database } \\
\text { construction of stored grain pests }\end{array}$ \\
\hline Guo, M.; Ph.D. [267] & 2003 & Shaanxi Normal Univ. & $\begin{array}{c}\text { Propagation of sound signals in quasi-porous media and analysis } \\
\text { of the sound properties of pests }\end{array}$ \\
\hline Guo, X.; Ph.D. [187] & 2007 & Zhejiang Univ. & $\begin{array}{c}\text { Study on wireless networked control system based on wireless } \\
\text { sensor networks }\end{array}$ \\
\hline Kiobia, D.O.; M.S. [280] & 2015 & Virginia Polytech. Inst. & $\begin{array}{c}\text { Design and development of a low-cost acoustic device to detect } \\
\text { pest infestation in stored maize }\end{array}$ \\
\hline Klaassen, R.E; M.S. [281] & 1989 & Purdue Univ. & $\begin{array}{c}\text { Identification of concealed insect infestations using a passive } \\
\text { ultrasound monitor }\end{array}$ \\
\hline Njoroge, A.W.; Ph.D. [282] & 2017 & Univ. Kassel & Acoustic detection of insect pests of stored grains in Kenya \\
\hline Pesho, G.R.; M.S. [283] & 1954 & Kansas State Col. & $\begin{array}{l}\text { Detection of immature rice weevils, Sitophilus oryzae L. } \\
\text { (Curculionidae, Coleoptera), by audio amplification }\end{array}$ \\
\hline Rigato, F.E.; M.S. [284] & 2013 & Univ Padua & $\begin{array}{c}\text { Indagini bioacustiche per l'identificazione di larve di Coleotteri } \\
\text { Cerambicidi (Coleoptera Cerambycidae) }\end{array}$ \\
\hline Schofield, J.; Ph.D. [285] & 2011 & Univ. York & $\begin{array}{l}\text { Real-time acoustic identification of invasive wood-boring beetles } \\
\text { Nondestructive evaluation of larval development and feeding }\end{array}$ \\
\hline Watanabe, H.; Ph.D. [35] & 2018 & Kyoto Univ. & $\begin{array}{l}\text { behavior of the bamboo powderpost beetle Dinoderus minutus in } \\
\text { bamboo culms }\end{array}$ \\
\hline Welp, H., Ph.D. [69] & 1994 & Humbolt-Universitat & $\begin{array}{l}\text { Acoustic detection of hidden larvae of several storage pests in } \\
\text { products from bioshops of Berlin }\end{array}$ \\
\hline Yanase, Y.; Ph.D. [47] & 2013 & Kyoto Univ. & $\begin{array}{l}\text { Development of acoustic emission and gas monitoring methods } \\
\text { for nondestructive detection of termite attack on wooden } \\
\text { structures }\end{array}$ \\
\hline
\end{tabular}

Acoustic technology provides detection of adult and hidden immature insects feeding in grain [59], as well as non-destructive detection of adults and immatures in storage bags, museum collections, aquatic habitats [286], and heritage buildings [57]. The information it provides is electronically transferable to private and public databases for use by researchers, research data alliances, and plant, animal, and human health protection and regulatory agencies [287]. Additional contributions to such databases will benefit future automation of analyses to monitor worldwide abundance, distribution, and diversity of insects [174]. In addition to its increasing usage noted in this report for detection and management of insect pests in stored grain, acoustic technology as well as relevant technology using other sensors is also of considerable interest for management of hidden pest insects underground and in trees, where other detection options may be destructive. All three of these acoustic detection applications enable automated insect pest detection, which will become more important as human populations increase and natural resources decrease. Until now, however, 
commercial insect detection devices have not yet fully achieved the versatility, ease of use, and cost-effectiveness of currently available cell phones, and are not rapidly supplanting pheromone or probe trap, sifting or other pest insect detection methods in general use. The potential of increased scalability and increased automation nevertheless continues to drive interest from commercial suppliers of insect acoustic detection technology.

Farmers and warehouse managers need information for decision support [288], not only at small sample and large international scales, but also at intermediate scales, which requires both short- and long-term monitoring [289]. Grain samples may need to be tested multiple times at many locations, and the information needs to be relevant to decisions made in local, regional, and international context. Frequently used and transported acoustic detection devices should be both highly sensitive and robust, which increases the costs of production and decreases usage unless the information provided contributes significantly to profits. It has been difficult to reduce costs and automate the interpretation of acoustic signals so that they provide inexpensive, relevant information to end users. Until now, it has been difficult to commercialize devices with such features. Additional research can provide lower-cost devices, greater user friendliness, and greater ease of transfer of relevant information to private and/or public databases. However, the ultimate solution to this conundrum may be to combine acoustic technology with other precision agriculture technologies [290], contributing to automated predictive models and adding value by enabling customization of management treatments at increasingly smaller scales. Some of these technologies already exist at small scale, such as FarmBot (San Luis Obispo, CA, USA).

\section{Conclusions}

For this report, we tested a new device to detect adult and immature insects in stored grain and reviewed the history of different applications of acoustic technology to management of stored product insect pests, described recent advances in automated methods of discriminating insect sounds from background noise as well as recently developed methods for analyzing sounds to distinguish different insects from each other, and reviewed the development of sensor systems applicable to detection of stored product insect pests. In addition, we presented short descriptions of research that has been conducted in recent years on stored product insect management in Europe, Asia, the US, Africa, and elsewhere. After a century of slow development of applications, the use of acoustic methods and automated analyses of pest insect sounds is beginning to develop rapidly, and automated monitoring and management of stored product insect pests is closer to becoming a reality.

Author Contributions: Conceptualization, D.H., R.M. and P.E.; methodology, R.M., D.H., M.G., P.E. and A.N.; software, R.M.; validation, R.M., D.H., M.G. and A.N.; formal analysis, R.M.; investigation, R.M., D.H., M.G., P.E. and A.N.; resources, R.M., D.H., M.G., P.E. and A.N.; data curation, R.M.; writing—original draft preparation, R.M. and D.H.; writing—review and editing, R.M., D.H., M.G., P.E. and A.N.; visualization, R.M. and D.H.; supervision, R.M. and D.H.; project administration, R.M. and D.H.; funding acquisition, R.M. All authors have read and agreed to the published version of the manuscript.

Funding: This research was funded in part by a grant from King Abdullah University of Science and Technology (Agreement \#58-6036-8-024F, Saudi Arabia), and was supported by the Fundamental Research Funds for the Central Universities (Grant No.GK202105006, China).

Institutional Review Board Statement: Not Applicable.

Data Availability Statement: The data presented in this study are available on request from the corresponding author.

Acknowledgments: We thank Everett Foreman for assistance in conducting experiments and Ilyas Potamitis for providing advice on the operation of the TreeVibes system. The use of trade, firm, or corporation names in the publication does not constitute an official endorsement or approval by the United States Department of Agriculture, Agricultural Research Service, or any product or service to the exclusion of others that may be suitable. The USDA is an equal opportunity provider and employer. 
Conflicts of Interest: The authors declare no conflict of interest. The funders had no role in the design of the study; in the collection, analyses, or interpretation of data; in the writing of the manuscript, or in the decision to publish the results.

\section{References}

1. Neethirajan, S.; Karunakaran, C.; Jayas, D.S.; White, N.D.G. Detection techniques for stored-product insects in grain. Food Control 2007, 18, 157-162. [CrossRef]

2. Mankin, R.W.; Hagstrum, D.W.; Smith, M.T.; Roda, A.L.; Kairo, M.T.K. Perspective and promise: A century of insect acoustic detection and monitoring. Am. Entomol. 2011, 57, 30-44. [CrossRef]

3. Mankin, R.W. Applications of acoustics in insect pest management. Cab Rev. 2012, 7, 1-7. [CrossRef]

4. Ekramirad, N.; Adedeji, A.A.; Alimardani, R. A review of non-destructive methods for detection of insect infestation in fruits and vegetables. Innov. Food Res. 2016, 2, 6-12.

5. Liu, H.; Lee, S.-H.; Chahl, J.S. A review of recent sensing technologies to detect invertebrates on crops. Precis. Agric. 2017, 18, 635-666. [CrossRef]

6. Kaushik, R.; Singhai, J. Sensing technologies used for monitoring and detecting insect infestation in stored grain. Int. J. Eng. Tech. 2018, 7, 169-173. [CrossRef]

7. Banga, K.S.; Kotwaliwale, N.; Mohapatra, D.; Giri, S.K. Techniques for insect detection in stored food grains: An overview. Food Control 2018, 94, 167-176. [CrossRef]

8. Stejskal, V.; Vendl, T.; Li, Z.; Aulicky, R. Minimal thermal requirements for development and activity of stored product and food industry pests (Acari, Coleoptera, Lepidoptera, Psocoptera, Diptera, and Blattodea): A review. Insects 2019, 10, 149. [CrossRef]

9. Lima, M.C.F.; de Almeida Leandro, M.E.D.; Valero, C.; Coronel, L.C.P.; Bazzo, C.O.G. Automated detection and monitoring of insect pests-A review. Agriculture 2020, 10, 161. [CrossRef]

10. Kovács, L.; Kézér, F.L.; Ruff, F.; Szenci, O. Rumination time and reticuloruminal temperature as possible predictors of dystocia in dairy cows. J. Dairy Sci. 2017, 100, 1568-1579. [CrossRef] [PubMed]

11. Lange, A.; Bauer, L.; Futschik, A.; Waiblinger, S.; Lürzel, S. Talking to cows: Reactions to different auditory stimuli during gentle human-animal interactions. Front. Psychol. 2020, 11, 579346. [CrossRef] [PubMed]

12. Hulme, P.E. Trade, transport and trouble; managing invasive species pathways in an era of globalization. J. Appl. Ecol. 2009, 46, 10-18. [CrossRef]

13. Fei, S.; Morin, R.S.; Oswalt, C.M.; Liebhold, A.M. Biomass losses resulting from insect and disease invasions in US forests. Proc. Natl. Acad. Sci. USA 2019, 116, 17371-17376. [CrossRef] [PubMed]

14. Scheffrahn, R.H.; Robbins, W.P.; Busey, P.; Su, N.Y.; Mueller, R.K. Evaluation of a novel, hand-held, acoustic emissions detector to monitor termites (Isoptera: Kalotermitidae, Rhinotermitidae) in wood. J. Econ. Entomol. 1993, 86, 1720-1729. [CrossRef]

15. Eliopoulos, P.A.; Potamitis, I.; Kontodimas, D.C.; Givropoulou, E.G. Detection of adult beetles inside the stored wheat mass based on their acoustic emissions. J. Econ. Entomol. 2015, 108, 2808-2814. [CrossRef]

16. Eliopoulos, P.A.; Potamitis, I.; Kontodimas, D.C. Estimation of population density of stored grain pests via bioacoustic detection. Crop Prot. 2016, 85, 71-78. [CrossRef]

17. Eliopoulos, P.; Potamitis, I. Detection and estimation of population density of bean weevils (Coleoptera: Bruchidae) in stored pulses via bioacoustic analysis. In Proceedings of the 12th International Working Conference on Stored Product Protection (IWCSPP), Berlin, Germany, 7-11 October 2018; pp. 272-275.

18. Njoroge, A.W.; Mankin, R.W.; Smith, B.W.; Baributsa, D. Effects of hermetic storage on adult Sitophilus oryzae L. (Coleoptera: Curculionidae) acoustic activity patterns and mortality. J. Econ. Entomol. 2017, 110, 2707-2715. [CrossRef]

19. Mankin, R.W.; Jetter, E.; Rohde, B.; Yasir, M. Performance of a low-cost acoustic insect detector system with Sitophilus oryzae (Coleoptera: Curculionidae) in stored grain and Tribolium castaneum (Coleoptera: Tenebrionidae) in flour. J. Econ. Entomol. 2020, 113, 3004-3010. [CrossRef]

20. Pesson, P.; Ozer, M. Use of an actograph with electro-acoustical detector for study of grain-insects. Actography of larval development of Sitophilus granarius. Detection of primary effects of ionizing radiations. Ann. Epiphyt. 1968, 19, 501-512.

21. Calkins, C.O.; Webb, J.C. Temporal and seasonal differences in movement of Caribbean fruit fly larvae in grapefruit and the relationship to detection by acoustics. Fla. Entomol. 1988, 71, 409-416. [CrossRef]

22. Litzkow, C.A.; Masuda, S. Acoustical detection of hidden insects. J. Acoust. Soc. Am. 1988, 83, 407. [CrossRef]

23. Klaassen, R.E.; Furgason, E.S. Characterization of the ultrasonic signals generated by concealed insects. In Proceedings of the IEEE Ultrasonics Symposium, Chicago, IL, USA, 2-5 October 1988; pp. 923-927.

24. Shade, R.E.; Furgason, E.S.; Murdock, L.L. Detection of hidden insect infestations by feeding-generated ultrasonic signals. Am. Entomol. 1990, 36, 231-234. [CrossRef]

25. Kirchner, W.H.; Broecker, I.; Tautz, J. Vibrational alarm communication in the damp-wood termite Zootermopsis nevadensis. Physiol. Entomol. 1994, 19, 187-190. [CrossRef]

26. Imamura, Y.; Fujii, Y. Analysis of feeding activities of termites by AE monitoring of infested wood (in Japanese). Mokuzai Hozon 1995, 21, 61-69. [CrossRef]

27. Imamura, Y.; Adachi, A.; Fujii, Y. Acoustic emission (AE) detected from wood attacked by powder-post beetles, Lyctus brunneus Stephens. Jpn. J. Environ. Entomol. Zool. 1998, 9, 98-100. 
28. Matsuoka, H.; Fujii, Y.; Okumura, S.; Imamura, Y.; Yoshimura, T. Relationship between the type of feeding behavior of termites and the acoustic emission (AE) generation. Wood Res. 1996, 83, 1-7.

29. Indrayani, Y. Feeding activities of a dry-wood termite, Cryptotermes domesticus (Haviland) under various relative humidity and temperature conditions using acoustic emission monitoring. Jpn. J. Environ. Entomol. Zool. 2003, 14, $205-212$.

30. Indrayani, Y.; Yoshimura, T.; Yanase, Y.; Fujii, Y.; Matsuoka, H.; Imamura, Y. Observation of feeding behavior of three termite (Isoptera) species: Incisitermes minor, Coptotermes formosanus, and Reticulitermes speratus. Sociobiology 2007, 49, 121-134.

31. Sulehrie, M.A.Q.; Golob, P.; Tran, B.M.D.; Farrell, G. Use of a biomonitor to assess the effect of seed hardness on larval feeding of Callosobruchus maculatus in Vigna varieties. Bioacoustics 2003, 14, 35-46. [CrossRef]

32. Sun, K.; Cao, Y.; Li, Y.; Li, G. Acoustic detection of walking and feeding activities of Tenebrio molitor Linnaeus adult. J. Henan Univ. Technol. (Nat. Sci. Ed.) 2008, 29, 39-44.

33. Bittner, J.A.; Balfe, S.; Pittendrigh, B.R.; Popovics, J.S. Monitoring of the cowpea bruchid, Callosobruchus maculatus (Coleoptera: Bruchidae), feeding activity in cowpea seeds: Advances in sensing technologies reveals new insights. J. Econ. Entomol. 2018, 111, 1469-1475. [CrossRef] [PubMed]

34. Watanabe, H.; Yanase, Y.; Fujii, Y. Relationship between the movements of the mouthparts of the bamboo powder-post beetle Dinoderus minutus and the generation of acoustic emission. J. Wood Sci. 2016, 62, 85-92. [CrossRef]

35. Watanabe, H. Nondestructive Evaluation of Larval Development and Feeding Behavior of the Bamboo Powderpost Beetle Dinoderus minutus in Bamboo Culms. Ph.D. Thesis, Kyoto University, Kyoto, Japan, 2018.

36. Thanthianga, C.; Mitchell, R. Vibrations mediate prudent resource exploitation by competing larvae of the bruchid bean weevil Callosobruchus maculatus. Entomol. Exp. Appl. 1987, 44, 15-21. [CrossRef]

37. Guedes, R.N.C.; Yack, J.E. Shaking youngsters and shaken adults: Female beetles eavesdrop on larval seed vibrations to make egg-laying decisions. PLOS ONE 2016, 11, e0150034.

38. Pittendrigh, B.R.; Huesing, J.E.; Shade, R.E.; Murdock, L.L. Monitoring of rice weevil, Sitophilus oryzae, feeding behavior in maize seeds and the occurrence of supernumerary molts in low humidity conditions. Entomol. Exp. Appl. 1997, 83, 225-231. [CrossRef]

39. Houng, H.Y.; Chou, J.M. Development of automatic bio-monitoring system for the life history of insect. Appl. Mech. Mater. Trans. Tech. Publ. 2012, 195, 1078-1082. [CrossRef]

40. Lewis, V.; Leighton, S.; Tabuchi, R.; Haverty, M. Seasonal and daily patterns in activity of the western drywood termite, Incisitermes minor (Hagen). Insects 2011, 2, 555-563. [CrossRef]

41. Walker, T.J. Effects of temperature, humidity, and age on stridulatory rates in Atlanticus spp. (Orthoptera: Tettigoniidae: Decticinae). Ann. Entomol. Soc. Am. 1975, 68, 607-611. [CrossRef]

42. Yusef, S.; Yanase, Y.; Sawada, Y.; Fujii, Y.; Yoshimura, T.; Imamura, Y. Evaluation of termites feeding activities by acoustics emission under various relative humidity $(\mathrm{RH})$ conditions. In Proceedings of the Third International Wood Science Symposium, Uji, Japan, 1-2 November 2000; pp. 173-178.

43. Nakayama, T.; Yanase, Y.; Yoshimura, T.; Imamura, Y. Effects of humidity changes on the feeding activity of a pest termite. Reticulitermes speratus (Kolbe). Jpn. J. Environ. Entomol. Zool. 2002, 13, 125-131.

44. Nakayama, T.; Yoshimura, T.; Imamura, Y. The optimum temperature-humidity combination for the feeding activities of Japanese subterranean termites. J. Wood Sci. 2004, 50, 530-534. [CrossRef]

45. Nakayama, T.; Yoshimura, T.; Imamura, Y. Feeding activities of Coptotermes formosanus Shiraki and Reticulitermes speratus (Kolbe) as affected by moisture content of wood. J. Wood Sci. 2005, 51, 60-65. [CrossRef]

46. Indrayani, Y.; Yoshimura, T.; Yanase, Y.; Fujii, Y.; Imamura, Y. Evaluation of the temperature and relative humidity preferences of the western dry-wood termite Incisitermes minor (Hagen) using acoustic emission (AE) monitoring. J. Wood Sci. 2007, 53, 76-79. [CrossRef]

47. Yanase, Y. Development of Acoustic Emission and Gas Monitoring Methods for Nondestructive Detection of Termite Attack on Wooden Structures. Ph.D. Thesis, Kyoto University, Kyoto, Japan, 2013.

48. Bilski, P.; Bobiński, P.; Krajewski, A.; Witomski, P. Detection of wood boring insects' larvae based on the acoustic signal analysis and the artificial intelligence algorithm. Arch. Acoust. 2017, 42, 61-70. [CrossRef]

49. Fleurat-Lessard, F.; Tomasini, B.; Kostine, L.; Fuzeau, B. Acoustic detection and automatic identification of insect stages activity in grain bulks by noise spectra processing through classification algorithms. In Proceedings of the 9th International Working Conference on Stored Product Protection, Sao Paulo, Brazil, 15-18 October 2006; pp. 476-486.

50. Hagstrum, D.W.; Flinn, P.W. Comparison of acoustical detection of several species of stored-grain beetles (Coleoptera: Curculionidae, Tenebrionidae, Bostrichidae, Cucujidae) over a range of temperatures. J. Econ. Entomol. 1993, 86, 1271-1278. [CrossRef]

51. Lewis, V.R.; Leighton, S.; Tabuchi, R.; Baldwin, J.A.; Haverty, M.I. Influence of environmental factors on activity patterns of Incisitermes minor (Isoptera: Kalotermitidae) in naturally infested logs. J. Econ. Entomol. 2013, 106, 338-346. [CrossRef] [PubMed]

52. Mousavi, S.F.; Abbaspour Fard, M.H.; Aghkani, M.H.; Namaghi, H.S.; Ebrahimi, E. Investigation of the effect of temperature on the activity of tooth weevil (Oryzaephilus surinamensis) by acoustic detection. Iran. Biosyst. Eng. 2017, 48, 111-117.

53. Nowakowska, M.; Krajewski, A.; Witomski, P.; Bobiński, P. Thermic limitation of AE detection method of old house borer larvae (Hylotrupes bajulus L.) in wooden structures. Constr. Build. Mater. 2017, 136, 446-449. [CrossRef]

54. Abram, P.K.; Boivin, G.; Moiroux, M.; Brodeur, J. Behavioral effects of temperature on ectothermic animals: Unifying thermal physiology and behavioural plasticity. Biol. Rev. 2017, 92, 1859-1876. [CrossRef] [PubMed] 
55. Nanda, M.A.; Seminar, K.B.; Nandika, D.; Maddu, A. A preliminary investigation of various signal phenomena generated by termite infestation. IOP Conf. Ser. Earth Environ. Sci. 2019, 335, 012030. [CrossRef]

56. Nanda, M.A.; Seminar, K.B.; Nandika, D.; Maddu, A. Development of termite detection system based on acoustic and temperature signals. Measurement 2019, 147, 106902. [CrossRef]

57. Krajewski, A.; Bilski, P.; Witomski, P.; Bobiński, P.; Gus, J. The progress in the research of AE detection method of old house borer larvae (Hylotrupes bajulus L.) in wooden structures. Constr. Build. Mat. 2020, 256, 119387. [CrossRef]

58. Mankin, R.W. Increase in acoustic detectability of Plodia interpunctella larvae after low-energy microwave radar exposure. Fla. Entomol. 2006, 89, 416-418. [CrossRef]

59. Hagstrum, D.W.; Flinn, P.W.; Gaffney, J. Temperature gradient on Tribolium castaneum (Coleoptera: Tenebrionidae) adult dispersal in stored wheat. Environ. Entomol. 1998, 27, 123-129. [CrossRef]

60. Nguyen, H.Q.; Serret, H.; Bae, Y.; Ji, S.; Chae, S.; Kim, Y.I.; Ha, J.; Jang, Y. Not all cicadas increase thermal tolerance in response to a temperature gradient in metropolitan Seoul. Sci. Rep. 2020, 10, 1343. [CrossRef] [PubMed]

61. Pearson, T.C.; Cetin, A.; Tewfik, A.; Haff, R. Feasibility of impact-acoustic emissions for detection of damaged wheat kernels. Digit. Signal Proc. 2007, 17, 617-633. [CrossRef]

62. Buerano, J.; Zalameda, J.; Ruiz, R. Microphone system optimization for free fall impact acoustic method in detection of rice kernel damage. Comp. Electron. Agric. 2012, 85, 140-148. [CrossRef]

63. Guo, M.; Ma, Y.; Zhao, Z.; Ma, M.; Wu, X.; Mankin, R.W. A new EEMD-based scheme for detection of insect damaged wheat kernels using impact acoustics. Acta Acust. United Acust. 2016, 102, 1108-1117. [CrossRef]

64. Sun, X.; Guo, M.; Ma, M.; Mankin, R.W. Identification and classification of damaged corn kernels with impact acoustics multi-domain patterns. Comp. Electron. Agric. 2018, 150, 152-161. [CrossRef]

65. Fesus, I.; Molnár, J. Elektroakusztikai Módszer a Raktári Kártevőt Okozta Fertőzés Kimutatására. (Electro-acoustic method for detecting infection caused by warehouse pests). Növényvédelem Plant Prot. 1975, 11, 452-461.

66. Hansen, J.D. Acoustical detection of the sweetpotato weevil (Coleoptera: Curculionidae) in sweet potato. J. Entomol. Sci. 1993, 28, 453-461. [CrossRef]

67. Kennedy, L.; Devereau, A.D. Observations on large-scale outdoor maize storage in jute and woven polypropylene sacks in Zimbabwe. In Proceedings of the 6th International Working Conference on Stored-Product Protection, Canberra, Australia, 17-23 April 1994; Highley, E., Wright, E.J., Banks, H.J., Champ, B.R., Eds.; CAB International: Wallingford, UK, 1994 ; pp. $290-295$.

68. Schwab, L.; Degoul, P. Automatic acoustical surveillance system of grains in silos. In Stored Malting Barley: Management of Quality using an Expert System; Fleurat-Lessard, F., Ndiaye, A., Knight, J.D., Eds.; INRA-Editions: Paris, France, 2005; pp. 203-218.

69. Welp, H. Acoustic Detection of Hidden Larvae of Several Storage Pests in Products from Bioshops of Berlin. Ph. D. Thesis, Humboltuniversitat, Berlin, Germany, 1994.

70. Leblanc, M.P.; Gaunt, D.; Fleurat-Lessard, F. Experimental study of acoustic equipment for real-time insect detection in grain bins-Assessment of their potential for infestation risk prediction during long term storage periods. IOBC WPRS Bull. 2011, 69, 79-88.

71. Kiobia, D.O.; Tumbo, S.D.; Cantillo, J.; Rohde, B.B.; Mallikarjunan, P.K.; Mankin, R.W. Characterization of sounds in maize produced by internally feeding insects: Investigations to develop inexpensive devices for detection of Prostephanus truncatus (Coleoptera: Bostrichidae) and Sitophilus zeamais (Coleoptera: Curculionidae) in small-scale storage facilities in Sub-Saharan Africa. Fla. Entomol. 2015, 98, 405-409.

72. Flynn, T.; Salloum, H.; Hull-Sanders, H.; Sedunov, A.; Sedunov, N.; Sinelnikov, Y.; Sutin, A.; Masters, D. Acoustic methods of invasive species detection in agriculture shipments. In Proceedings of the 2016 IEEE Symposium on Technologies for Homeland Security (HST), Waltham, MA, USA, 10-12 May 2016; pp. 1-5.

73. Sutin, A.; Flynn, T.; Sedunov, N.; Salloum, H.; Sedunov, A.; Masters, D. Acoustic methods of pest detection in agricultural shipments. J. Acoust. Soc. Am. 2016, 140, 3180. [CrossRef]

74. Njoroge, A.W.; Mankin, R.W.; Smith, B.; Baributsa, D. Effects of hypoxia on acoustic activity of two stored-product pests, adult emergence, and grain quality. J. Econ. Entomol. 2019, 112, 1989-1996. [CrossRef] [PubMed]

75. Njoroge, A.W.; Affognon, H.; Mutungi, C.; Richter, U.; Hensel, O.; Rohde, B.; Mankin, R.W. Bioacoustics of Acanthoscelides obtectus (Coleoptera: Chrysomelidae: Bruchinae) on Phaseolus vulgaris (Fabaceae). Fla. Entomol. 2017, 100, 109-115. [CrossRef]

76. Lewis, V.R.; Lemaster, R.L. The potential of using acoustical emission to detect termites within wood. In Proceedings of the Symposium Current Research on Wood-Destroying Organisms and Future Prospects for Protecting Wood in Use, Bend, OR, USA, 13 September 1989; General Technical Report; Haverty, M.I., Wilcox, W.W., Eds.; USDA Forest Service: Washington, DC, USA, 1991; pp. 34-37.

77. Lewis, V.R.; Lemaster, R.; Beall, F.; Wood, D. Using AE monitoring for detecting economically important species of termites in California. In The International Research Group on Wood Preservation 22nd Annual Meeting Proceedings; IRG Document No. IRG/WP/2375; IRG Secretariat: Stockholm, Sweden, 1991; pp. 1-8.

78. Fujii, Y.; Imamura, Y.; Shibata, E.; Noguchi, M. Feasibility of AE (Acoustic Emission) monitoring for the detection of the activities of wood destroying insects. In Proceedings of the Annual Meeting- International Research Group on Wood Preservation, Harrogate, UK, 10-15 May 1992; No. 92-2416, p. 9.

79. Fujii, Y.; Imamura, Y.; Yoshimura, T. Observation of feeding behavior of termite using CCD camera and its relation to the generation of acoustic emission (AE). Wood Res. 1995, 82, 47-53. 
80. Fujii, Y.; Yanase, Y.; Imamura, Y.; Okumura, S.; Oka, S. Detection of termite attack in wooden buildings with AE monitoring: Case study at a traditional Japanese warehouse. Jpn. J. Environ. Entomol. Zool. 1998, 9, 101-105.

81. Fujii, Y.; Yanase, Y. Non-destructive evaluation of decay and insect attack in wood using acoustic emission (AE) monitoring and a radar technique. Tools for maintaining wood and outdoor applications. In High-Performance Utilization of Wood for Outdoor Uses; Imamura, Y., Ed.; Press-Net: Kyoto, Japan, 2001; pp. 145-160.

82. Evans, T.A.; Lai, J.C.S.; Toledano, E.; McDowall, L.; Rakotonarivo, S.; Lenz, M. Termites assess wood size by using vibration signals. Proc. Natl. Acad. Sci. USA 2005, 102, 3732-3737. [CrossRef] [PubMed]

83. Mankin, R.W.; Benshemesh, J. Geophone detection of subterranean termite and ant activity. J. Econ. Entomol. 2006, 99, 244-250. [CrossRef]

84. Fujii, Y.; Narahara, K.; Fujiwara, Y.; Ngatsuma, T.; Yonas, Y.; Yoshimu, T.; Okumura, S.; Imamura, Y. Nondestructive detection of termites using a millimeter-wave imaging technique. For. Prod. J. 2007, 57, 75-79.

85. Farr, I.; Chesmore, D. Automated bioacoustic detection and identification of wood-boring insects for quarantine screening and insect ecology. Proc. Inst. Acoust. 2007, 29, 201-208.

86. Mankin, R.W.; Osbrink, W.L.; Oi, F.M.; Anderson, J.B. Acoustic detection of termite infestations in urban trees. J. Econ. Entomol. 2002, 95, 981-988. [CrossRef] [PubMed]

87. Mankin, R.W.; Smith, M.T.; Tropp, J.M.; Atkinson, E.B.; Jong, D.Y. Detection of Anoplophora glabripennis (Coleoptera: Cerambycidae) larvae in different host trees and tissues by automated analyses of sound-impulse frequency and temporal patterns. J. Econ. Entomol. 2008, 101, 838-849. [CrossRef]

88. Evans, T.A.; Inta, R.; Lai, J.C.S.; Prueger, S.; Foo, N.W.; Fu, E.W.; Lenz, M. Termites eavesdrop to avoid competitors. Proc. R. Soc. B 2009, 276, 4035-4041. [CrossRef] [PubMed]

89. Mankin, R.W.; Moore, A. Acoustic detection of Oryctes rhinoceros (Coleoptera: Scarabaeidae: Dynastinae) and Nasutitermes luzonicus (Isoptera: Termitidae) in palm trees in urban Guam. J. Econ. Entomol. 2010, 103, 1135-1143. [CrossRef] [PubMed]

90. Noguchi, M.; Fujii, Y.; Owada, M.; Imamura, Y.; Tokoro, M.; Tooya, R. AE monitoring to detect termite attack on wood of commercial dimension and posts. For. Prod. J. 1991, 41, 32-36.

91. Pinhas, J.; Soroker, V.; Hetzroni, A.; Mizrach, A.; Teicher, M.; Goldberger, J. Automatic acoustic detection of the red palm weevil. Comp. Electron. Agric. 2008, 63, 131-139. [CrossRef]

92. Siriwardena, K.A.P.; Fernando, L.C.P.; Nanayakkara, N.; Perera, K.F.G.; Kumara, A.D.N.; Nanayakkara, T.T. Portable acoustic device for detection of coconut palms infested by Rhynchophorus ferrugineus (Coleoptera: Curculionidae). Crop Prot. 2010, 29, 25-29. [CrossRef]

93. Sivaraman, K.; Moni, R.S.; Ramachandran, S.C.P. Red palm weevil detector. Invent. Intell. 1989, 24, 32-35.

94. Oliver-Villanueva, J.V.; Abián-Pérez, M.A. Advanced wireless sensors for termite detection in wood constructions. Wood Sci. Technol. 2013, 47, 269-280. [CrossRef]

95. Oh, J.; Lee, J. Feasibility of ultrasonic spectral analysis for detecting insect damage in wooden cultural heritage. J. Wood Sci. 2014, 60, 21-29. [CrossRef]

96. Oh, J.K.; Kim, C.K.; Hong, J.P. Improvements of robustness in ultrasonic attenuation spectroscopy for detecting internal insect damage in wood member of cultural heritage. J. Wood Sci. 2015, 61, 136-142. [CrossRef]

97. Le Conte, S.; Vaiedelich, S.; Thomas, J.-H.; de Reyer, D.; Maurin, E. Acoustic emission to detect xylophagous insects in wooden musical instrument. J. Cult. Herit. 2015, 16, 338-343. [CrossRef]

98. Hetzroni, A.; Soroker, V.; Cohen, Y. Toward practical acoustic red palm weevil detection. Comp. Electron. Agric. 2016, 124, 100-106. [CrossRef]

99. Mankin, R.W.; Al-Ayedh, H.Y.; Aldryhim, Y.; Rohde, B. Acoustic detection of Rhynchophorus ferrugineus (Coleoptera: Dryophthoridae) and Oryctes elegans (Coleoptera: Scarabaeidae) in Phoenix dactylifera (Arecales: Arecacae) trees and offshoots in Saudi Arabian orchards. J. Econ. Entomol. 2016, 109, 622-628. [CrossRef] [PubMed]

100. Mankin, R.W.; Burman, H.; Menocal, O.; Carrillo, D. Acoustic detection of Mallodon dasystomus (Coleoptera: Cerambycidae) in Persea americana (Laurales: Lauraceae) branch stumps. Fla. Entomol. 2018, 101, 321-323. [CrossRef]

101. El-Hadad, A. Using Acoustic Emission Technique with MATLAB Analysis to Detect Termites in Timber-in-Service. Ph.D. Thesis, The University of Melbourne, Melbourne, Australia, 2017.

102. Green, F.; Boardman, C.; Munson, R. Remote Detection of Termite Activity in Wooden Bridge Structures; General Technical Report; USDA Forest Service: Washington, DC, USA, 2018; pp. 1-18. [CrossRef]

103. Jalinas, J.; Güerri-Agulló, B.; Dosunmu, O.G.; Haseeb, M.; Lopez-Llorca, L.V.; Mankin, R.W. Acoustic signal applications in detection and management of Rhynchophorus spp. in fruit-crops and ornamental palms. Fla. Entomol. 2019, 102, 475-479. [CrossRef]

104. Rach, M.M.; Gomis, H.M.; Granado, O.L.; Malumbres, M.P.; Campoy, A.M.; Martín, J.J.S. On the design of a bioacoustic sensor for the early detection of the red palm weevil. Sensors 2013, 13, 1706-1729. [CrossRef]

105. Creemers, J. Use of acoustic emission (AE) to detect activity of common European dry-woodboring insects: Practical considerations. In Proceedings of the International Symposium Non-Destructive Testing Civil Engineering (NDT-CE), Berlin, Germany, 15-17 September 2015; pp. 15-17.

106. Sutin, A.; Yakubovskiy, A.; Salloum, H.; Flynn, T.; Sedunov, N.; Nadel, H.; Krishnankutty, S. Sound of wood-boring larvae and its automated detection. J. Acoust. Soc. Am. 2018, 143, 1795. [CrossRef] 
107. Sutin, A.; Yakubovskiy, A.; Salloum, H.R.; Flynn, T.J.; Sedunov, N.; Nadel, H. Towards an automated acoustic detection algorithm for wood-boring beetle larvae (Coleoptera: Cerambycidae and Buprestidae). J. Econ. Entomol. 2019, 112, 1327-1336. [CrossRef] [PubMed]

108. Hansen, J.D.; Webb, J.C.; Armstrong, J.W.; Brown, S.A. Acoustical detection of oriental fruit fly (Diptera: Tephritidae) larvae in papaya. J. Econ. Entomol. 1988, 81, 963-965. [CrossRef]

109. Brandhorst-Hubbard, J.L.; Flanders, K.L.; Mankin, R.W.; Guertal, E.A.; Crocker, R.L. Mapping of soil insect infestations sampled by excavation and acoustic methods. J. Econ. Entomol. 2001, 94, 1452-1458. [CrossRef]

110. Mankin, R.W. Acoustical detection of Aedes taeniorhynchus swarms and emergence exoduses in remote salt marshes. J. Am. Mosq. Cont. Assoc. 1994, 10, 302-308.

111. Mankin, R.W.; Brandhorst-Hubbard, J.; Flanders, K.L.; Zhang, M.; Crocker, R.L.; Lapointe, S.L.; McCoy, C.W.; Fisher, J.R.; Weaver, D.K. Eavesdropping on insects hidden in soil and interior structures of plants. J. Econ. Entomol. 2000, 93, 1173-1182. [CrossRef]

112. Mankin, R.W.; Lapointe, S.L.; Franqui, R.A. Acoustic surveying of subterranean insect populations in citrus groves. J. Econ. Entomol. 2001, 94, 853-859. [CrossRef]

113. Mankin, R.W.; Weaver, D.K.; Grieshop, M.; Larson, B.; Morrill, W.L. Acoustic system for insect detection in plant stems: Comparisons of Cephus cinctus in wheat and Metamasius callizona in bromeliads. J. Agric. Urban Entomol. 2004, 21, $239-248$.

114. Mankin, R.W.; Hubbard, J.L.; Flanders, K.L. Acoustic indicators for mapping infestation probabilities of soil invertebrates. J. Econ. Entomol. 2007, 100, 790-800. [CrossRef] [PubMed]

115. Mankin, R.W.; Fisher, J.R. Acoustic detection of black vine weevil, Otiorhynchus sulcatus (Fabricius) (Coleoptera: Curculionidae) larval infestations in nursery containers. J. Environ. Hort. 2002, 20, 166-170. [CrossRef]

116. Mankin, R.W.; Fisher, J.R. Current and potential uses of acoustic systems for detection of soil insect infestations. In Proceedings of the Fourth Symposium on Agroacoustics, Oxford, MS, USA, 6-9 May 2002; pp. 152-158.

117. Schneider, K. Acoustical detection of pink bollworms in cotton bolls. Beltwide Cotton Conf. 1995, 2, $1054-1057$.

118. Sharp, J.L.; Thalman, R.K.; Webb, J.C.; Masuda, S. Flexible acoustical device to detect feeding sounds of Caribbean fruit fly (Diptera: Tephritidae) larvae in mango, cultivar Francis. J. Econ. Entomol. 1988, 81, 406-409. [CrossRef]

119. Spangler, H.G. Detecting lesser wax moths acoustically. Glean. Bee Cult. 1985, 113, 207-209.

120. Lampson, B.D.; Han, Y.J.; Khalilian, A.; Greene, J.; Mankin, R.W.; Foreman, E.G. Automatic detection and identification of brown stink bug, Euschistus servus and southern green stink bug, Nezara viridula, using intraspecific substrate-borne vibrational signals. Comp. Electron. Agric. 2013, 91, 154-159. [CrossRef]

121. Vinatier, F.; Vinatier, D. Acoustic recording as a non-invasive method to detect larval infestation of Cosmopolites sordidus. Entomol. Exp. Appl. 2013, 149, 22-26. [CrossRef]

122. Qandour, A.; Ahmad, I.; Habibi, D.; Leppard, M. Remote beehive monitoring using acoustic signals. Acoust. Aust. 2014, 42, 204-209.

123. Li, M.; Ekramirad, N.; Rady, A.; Adedeji, A. Application of acoustic emission and machine learning to detect codling moth infested apples. Trans. ASABE 2018, 61, 1157-1164. [CrossRef]

124. Inyang, E.I.; Hix, R.L.; Tsolova, V.; Rohde, B.B.; Dosunmu, O.; Mankin, R.W. Subterranean acoustic activity patterns of Vitacea polistiformis (Lepidoptera: Sesiidae) in relation to abiotic and biotic factors. Insects 2019, 10, 267. [CrossRef] [PubMed]

125. Hagstrum, D.W.; Webb, J.C.; Vick, K.W. Acoustical detection and estimation of Rhyzopertha dominica (F.) larval populations in stored wheat. Fla. Entomol. 1988, 71, 441-447. [CrossRef]

126. Hagstrum, D.W.; Vick, K.W.; Webb, J.C. Acoustical monitoring of Rhyzopertha dominica (E) (Coleoptera: Bostrichidae) populations in stored wheat. J. Econ. Entomol. 1990, 83, 625-628. [CrossRef]

127. Hagstrum, D.W.; Vick, K.W.; Flinn, P.W. Automated acoustical monitoring of Tribolium castaneum (Coleoptera: Tenebrionidae) populations in stored wheat. J. Econ. Entomol. 1991, 84, 1604-1608. [CrossRef]

128. Hagstrum, D.W.; Flinn, P.W.; Shuman, D. Automated monitoring using acoustical sensors for insects in farm-stored wheat. J. Econ. Entomol. 1996, 89, 211-217. [CrossRef]

129. Zhang, M.; Crocker, R.L.; Mankin, R.W.; Flanders, K.L.; Brandhorst-Hubbard, J.L. Acoustic estimation of infestations and population densities of white grubs (Coleoptera: Scarabaeidae) in turfgrass. J. Econ. Entomol. 2003, 96, 1770-1779. [CrossRef] [PubMed]

130. Banga, K.S.; Kotwaliwale, N.; Mohapatra, D.; Giri, S.K.; Bargale, P.C. Assessment of bruchids density through bioacoustic detection and artificial neural network (ANN) in bulk stored chickpea and green gram. J. Stored Prod. Res. 2020, 88, 101667. [CrossRef]

131. Eliopoulos, P.A.; Givropoulou, E.G.; Potamitis, I.; Kontodimas, D.C. Population density estimation of stored grain pests based on their acoustic emissions. IOBC WPRS Bull. 2014, 98, 65.

132. Poland, T.M.; Rassati, D. Improved biosecurity surveillance of non-native forest insects: A review of current methods. J. Pest Sci. 2019, 92, 37-49. [CrossRef]

133. Jalinas, J.; Güerri-Agulló, B.; Mankin, R.W.; Lopez-Follana, R.; Lopez-Llorca, L.V. Acoustic assessment of Beauveria bassiana (Hypocreales: Clavicipitaceae) effects on Rhynchophorus ferrugineus (Coleoptera: Dryophthoridae) larval activity and mortality. J. Econ. Entomol. 2015, 108, 444-453. [CrossRef] 
134. Jalinas, J.; Güerri-Agulló, B.; Dosunmu, O.G.; Lopez-Llorca, L.V.; Mankin, R.W. Acoustic activity cycles of Rhynchophorus ferrugineus (Coleoptera: Dryophthoridae) early instars after Beauveria bassiana (Hypocreales: Clavicipitaceae) treatments. Ann. Entomol. Soc. Am. 2017, 110, 551-557. [CrossRef]

135. Devereau, A.D.; Gudrups, I.; Appleby, J.H.; Credland, P.F. Automatic rapid screening of seed resistance in cowpea, Vigna unguiculata (L.) Walpers, to the seed beetle Callosobruchus maculatus (F.) (Coleoptera: Bruchidae) using acoustic monitoring. J. Stored Prod. Res. 2003, 39, 117-129. [CrossRef]

136. Lewis, V.R.; Power, A.B.; Haverty, M.I. Surface and subsurface sensor performance in acoustically detecting the western drywood termite in naturally infested boards. For. Prod. J. 2004, 54, 57-62.

137. Nasswettrová, A.; Křivánková, S.; Šmíra, P.; Štěpánek, P.; Friedl, M.; Trubák, J. Acoustic detection of wood-destroying insects during hot air treatment. Wood Res. 2016, 61, 755-766.

138. Njoroge, A.W.; Mankin, R.W.; Smith, B.W.; Baributsa, D. Oxygen consumption and acoustic activity of adult Callosobruchus maculatus (F.) (Coleoptera: Chrysomelidae: Bruchinae) during hermetic storage. Insects 2018, 9, 45. [CrossRef]

139. Morgan, T.D.; Oppert, B.; Czapla, T.H.; Kramer, K.J. Avidin and streptavidin as insecticidal and growth inhibiting dietary proteins. Entomol. Exp. Appl. 1993, 69, 97-108. [CrossRef]

140. Thoms, E.M. Use of an acoustic emissions detector and intergallery injection of spinosad by pest control operators for remedial control of drywood termites (Isoptera: Kalotermitidae). Fla. Entomol. 2000, 83, 64-74. [CrossRef]

141. Krajewski, A.; Kozyra, K.; Wójcik, A.; Witowski, P.; Bogusław, A.; Bobiński, P. The use of electro-acoustics in the evaluation of the effectiveness of old house borer in wood with p-dichlorobenzene. Lisowe Gospod. Lisowa Pap. Dieriewoobrobna Promistowist 2011, $37,114-116$.

142. Osbrink, W.; Cornelius, M. Acoustic evaluation of trees for Coptotermes formosanus Shiraki (Isoptera: Rhinotermitidae) treated with imidacloprid and noviflumuron in historic Jackson Square, New Orleans. Sociobiology 2013, 60, 77-95. [CrossRef]

143. Osbrink, W.; Cornelius, M.; Showler, A.T.; Pound, J.M. Effects of a fipronil spot treatment on field colonies of Coptotermes formosanus (Isoptera: Rhinotermitidae). J. Econ. Entomol. 2014, 107, 727-740. [CrossRef]

144. Mankin, R.W.; Machan, R.; Jones, R. Field testing of a prototype acoustic device for detection of Mediterranean fruit flies flying into a trap. In Proceedings of the 7th International Symposium on Fruit Flies of Economic Importance, Salvador, Brazil, 10-15 September 2006; pp. 165-169.

145. Schouest, L.P.; Miller, T.A. Automated pheromone traps show male pink bollworm (Lepidoptera: Gelechiidae) mating response is dependent upon weather conditions. J. Econ. Entomol. 1994, 87, 965-974. [CrossRef]

146. Walker, T.J. Acoustic traps for agriculturally important insects. Fla. Entomol. 1988, 71, 484-492. [CrossRef]

147. Ikeshoji, T.; Yap, H.H. Monitoring and chemosterilization of a mosquito population, Culex quinquefasciatus (Diptera: Culicidae) by sound traps. Appl. Entomol Zool. 1987, 22, 474-481. [CrossRef]

148. Tobin, P.C.; Klein, K.T.; Leonard, D.S. Gypsy moth (Lepidoptera: Lymantriidae) flight behavior and phenology based on field-deployed automated pheromone-baited traps. Environ. Entomol. 2009, 38, 1555-1562. [CrossRef] [PubMed]

149. Mueller-Blenkle, C.; Kirchner, S.; Szallies, I.; Adler, C. A new approach to acoustic insect detection in grain storage. In Proceedings of the 12th International Working Conference on Stored Product Protection (IWCSPP), Berlin, Germany, 7-11 October 2018; pp. 328-337.

150. Potamitis, I.; Eliopoulos, P.; Rigakis, I. Automated remote insect surveillance at a global scale and the internet of things. Robotics 2017, 6, 19. [CrossRef]

151. Johnson, B.J.; Rohde, B.B.; Zeak, N.; Staunton, K.M.; Prachar, T.; Ritchie, S.A. A low-cost, battery-powered acoustic trap for surveilling male Aedes aegypti during rear-and-release operations. PLoS ONE 2018, 13, e0201709. [CrossRef]

152. Rohde, B.B.; Staunton, K.M.; Zeak, N.C.; Beebe, N.; Snoad, N.; Bondarenco, A.; Liddington, C.; Anderson, J.A.; Wei, X.; Mankin, R.W.; et al. Waterproof, low-cost, long-battery-life sound trap for surveillance of male Aedes aegypti for rear-and-release mosquito control programmes. Parasites Vectors 2019, 12, 417. [CrossRef]

153. Yan, S.; Shang, Z.; Bai, Y. Design of sound insulation chamber for sound storage of stored pests. J. Shaanxi Norm. Univ. 2005, 33, 50-52.

154. Geng, S.; Li, F. Design of isolation booth for stored grain insect sound detection. Appl. Mech. Mater. 2012, 220-223, 1598-1601. [CrossRef]

155. Sharan, R.V.; Moir, T.J. An overview of applications and advancements in automatic sound recognition. Neurocomputing 2017, 200, 22-34. [CrossRef]

156. LeCun, Y.; Bengio, J.; Hinton, G. Deep learning. Nature 2015, 521, 436-444. [CrossRef]

157. Jennings, S.G.; Chen, J. Masking of short tones in noise: Evidence for envelope-based, rather than energy-based detection. J. Acoust. Soc. Am. 2020, 148, 211-221. [CrossRef] [PubMed]

158. Mankin, R.W. Eavesdropping on coconut rhinoceros beetles, red pal weevils, Asian longhorned beetles, and other invasive travelers. Proc. Meet. Acoust. 2011, 14, 010001.

159. Han, A.; He, Y.; Li, J.; Chen, Z.; Sun, Y. Design of acoustic signal acquisition system of stored grain pests based on wireless sensor networks. Trans. CSAE 2010, 26, 181-187.

160. Potamitis, I.; Rigakis, I.; Tatlas, N.-A.; Potirakis, S. In-vivo vibroacoustic surveillance of trees in the context of the IoT. Sensors 2019, 19, 1366. [CrossRef]

161. Murata, N.; Yoshizawa, S.; Amari, S.I. Network information criterion-determining the number of hidden units for an artificial neural network model. IEEE Trans. Neural Netw. 1994, 5, 865-872. [CrossRef] [PubMed] 
162. Dong, X.; Yan, N.; Wei, Y. Insect sound recognition based on convolutional neural network. In Proceedings of the 2018 IEEE 3 rd International Conference on Image, Vision and Computing (ICIVC), Chongqing, China, 27-29 June 2018; pp. 855-859.

163. Romano, J.M.; Brindza, J.P.; Kuchenbecker, K.J. ROS open-source audio recognizer: ROAR environmental sound detection tools for robot programming. Auton. Robot 2013, 34, 207-215. [CrossRef]

164. Jordan, M.I.; Mitchell, T.M. Machine learning: Trends, perspectives, and prospects. Science 2015, 349, 255-260. [CrossRef] [PubMed]

165. Rathore, D.S.; Ram, B.; Pal, B.L.; Malviya, S. Analysis of classification algorithms for insect detection using MATLAB. In Proceedings of the 2nd International Conference on Advanced Computing and Software Engineering (ICACSE) 2019, Sultanpur, India, 8-9 February 2019; pp. 299-302.

166. Campos, I.B.; Fewster, R.; Truskinger, A.; Towsey, M.; Roe, P.; Filho, D.V.; Lee, W.; Gaskett, A. Assessing the potential of acoustic indices for protected area monitoring in the Serra do Cipó National Park, Brazil. Ecol. Indic. 2021, 120, 106953. [CrossRef]

167. Rodriguez, B.; Lee, J.; Lufti, R. Additivity of segregation cues in simulated cocktail-party listening. J. Acoust. Soc. Am. 2021, 149, 82-86. [CrossRef] [PubMed]

168. Mankin, R.W.; Hodges, R.D.; Nagle, H.T.; Schal, C.; Pereira, R.M.; Koehler, P.G. Acoustic indicators for targeted detection of stored product and urban insect pests by inexpensive infrared, acoustic, and vibrational detection of movement. J. Econ. Entomol. 2010, 103, 1636-1646. [CrossRef]

169. Wong, E.; Sridharan, S. Comparison of linear prediction cepstrum coefficients and mel-frequency cepstrum coefficients for language identification. In Proceedings of the 2001 International Symposium on Intelligent Multimedia, Video and Speech Processing. ISIMP 2001 (IEEE Cat. No.01EX489), Hong Kong, China, 2-4 May 2001; pp. 95-98.

170. Erzin, E.; Cetin, A.E.; Yardimci, Y. Subband analysis for robust speech recognition in the presence of car noise. In Proceedings of the 1995 International Conference on Acoustics, Speech, and Signal Processing, Detroit, MI, USA, 9-12 May 1995; Volume 1, pp. 417-420.

171. Santiago, R.M.C.; Rabano, S.L.; Billones, R.K.D.; Calilung, E.J.; Sybingco, E.; Dadios, E.P. Insect detection and monitoring in stored grains using MFCCs and artificial, neural network. In Proceedings of the TENCON 2017-2017 IEEE Region 10 Conference, Penang, Malaysia, 5-8 November 2017; pp. 2542-2547.

172. Zhang, Y.; Guo, M.; Qin, X. Analysis of insect activity sounds in stored grain based on wavelet packet decompose. J. Huazhong Agric. Univ. 2013, 32, 135-140.

173. Mankin, R.W.; Stanaland, D.; Haseeb, M.; Rohde, B.; Menocal, O.; Carrillo, D. Assessment of plant structural characteristics, health, and ecology using bioacoustic tools. Proc. Meet. Acoust. 2018, 33, 010003.

174. Høye, T.T.; Ärje, J.; Bjerge, K.; Hansen, O.L.P.; Iosifidis, A.; Leese, F.; Mann, H.M.R.; Meissner, K.; Melvad, C.; Raitoharju, J. Deep learning and computer vision will transform entomology. Proc. Natl. Acad. Sci. USA 2021, 118, e2002545117. [CrossRef] [PubMed]

175. Kiskin, I.; Zili, D.; Li, Y.; Sinka, M.; Willis, K.; Roberts, S. Bioacoustic detection with wavelet-conditioned convolutional neural networks. Neural Comp. Appl. 2020, 32, 915-927. [CrossRef]

176. Mucherino, A.; Papajorgji, P.; Pardalos, P.M. A survey of data mining techniques applied to agriculture. Oper. Res. Int. J. 2009, 9, 121-140. [CrossRef]

177. Vick, K.W.; Webb, J.C.; Weaver, B.A.; Litzkow, C. Sound detection of stored product insects that feed inside kernels of grain. J. Econ. Entomol. 1988, 81, 1489-1493. [CrossRef]

178. Webb, J.C.; Litzkow, C.A.; Slaughter, D.C. A computerized acoustical larval detection system. Appl. Eng. Agric. 1988, 4, 268-274.

179. Webb, J.C.; Slaughter, D.C.; Litzkow, C.A. Acoustical system to detect larvae in infested commodities. Fla. Entomol. 1988, 71, 492-504. [CrossRef]

180. Han, P.; Zhang, H. Feature extraction of acoustic signals in the classification and identification of storage pests. Comp. Eng. Appl. 2003, 14, 215-217.

181. Geng, S.; Shang, Z. The sampling of the insect activity sound in the storage grain and its frequency spectrum analysis. J. Southwest China Norm. Univ. (Nat. Sci. Ed.) 2005, 30, 1057-1060.

182. Geng, S.; Shang, Z. The distinction of insect kind on the characteristic of stored grain insect sound frequency. Syst. Sci. Comp. Stud. Agric. 2005, 21, 241-243.

183. Guo, M.; Shang, Z.; Yan, S. Establishment and experimental verification of theoretical model of acoustic wave propagation in grain. J. Yunnan Univ. (Nat. Sci. Ed.) 2005, 27, 228-231.

184. Guo, M.; Shang, Z.; Bai, Y. Feature extraction and analysis of weak acoustic signals of stored grain pests. J. Yunnan Univ. 2006, 28, 497-503.

185. Kirchner, S.M.; Muller-Blenkle, C.; Adler, C.; Hensel, O.O. Robust classification of bearing damage based on its noise signatureThe basis for the implementation of an acoustic detection method. In Proceedings of the 60th Deutsche Pflanzenschutztagung, Martin-Luther-Universität, Halle-Wittenberg, Germany, 20-23 September 2016.

186. Shuman, D.; Coffelt, J.A.; Vick, K.W.; Mankin, R.W. Quantitative acoustical detection of larvae feeding inside kernels of grain. J. Econ. Entomol. 1993, 86, 933-938. [CrossRef]

187. Guo, X. Study on Wireless Networked Control System Based on Wireless Sensor Networks. Ph.D. Thesis, Zhejiang University, Hangzhou, China, 2007.

188. Han, A.; He, Y.; Li, J.; Chen, Z.; Zhao, Z. Design of multi-parameter automatic measuring system for stored grain condition based on wireless sensor networks. Trans. CSAE 2011, 27, 231-237. 
189. Guo, X.; Chen, W. Resource-saving audio signal acquisition methods based on compressed sensing theory. Trans. Chin. Soc. Agric. Eng. 2013, 29, 174-181.

190. Moore, A. Artificial neural network trained to identify mosquitoes in flight. J. Insect Behav. 1991, 4, 391-395. [CrossRef]

191. Coggins, K.M.; Principe, J. Detection and classification of insect sounds in a grain silo using a neural network. IEEE Explore 1998, 3, 1760-1765.

192. Moore, A.; Miller, R.H. Automated identification of optically sensed aphid (Homoptera: Aphidae) wingbeat waveforms. Ann. Entomol. Soc. Am. 2002, 95, 1-8. [CrossRef]

193. Al-Saqer, S.M.; Hassan, G.M. Artificial neural networks based red palm weevil (Rhynchophorus ferruginous, Olivier) recognition system. Am. J. Agric. Biol. Sci. 2011, 6, 356-364. [CrossRef]

194. Zhu, L. Insect sound recognition based on MFCC and PNN. In Proceedings of the 2011 International Conference on Multimedia and Signal Processing, Guilin, China, 14-15 May 2011; pp. 42-46.

195. Monaghan, J.J.M.; Goehring, T.; Yang, X.; Boiner, F.; Wang, S.; Wright, M.C.M.; Bleek, S. Auditory inspired machine learning techniques can improve speech intelligibility and quality for hearing-impaired listeners. J. Acoust. Soc. Am. 2017, 141, 1985-1998. [CrossRef]

196. Healy, E.W.; Delfarah, M.; Johnson, E.M.; Wang, D. A deep learning algorithm to increase intelligibility for hearing-impaired listeners in the presence of a competing talker and reverberation. J. Acoust. Soc. Am. 2019, 145, 1378-1388. [CrossRef]

197. Guo, M.; Shang, Z. Time-frequency analyze acoustical signals of pests in stored grain by MATLAB. J. Shaanxi Norm. Univ. Nat. Sci. Ed. 2002, 30, 62-66.

198. Guo, M.; Shang, Z.; Shi, H. Experimental study on the characteristics of grain absorption spectrum. J. Appl. Sci. 2003, 21, 111-116.

199. Han, P. Voice-pattern recognition of stored product insects. Comp. Eng. 2003, 29, 151-154.

200. Yan, S.; Shang, Z. Identification of pests in stored grain based on the characteristics of pest audio frequency domain. Agric. Syst. Sci. Compr. Res. 2005, 21, 241-243.

201. Geng, S.; Shang, Z. Studying frequency characteristic of insect activity sound in grain. J. Shaanxi Norm. Univ. 2006, 34, 47-50.

202. Potamitis, T.; Ganchev, T.; Fakotakis, N. Automatic acoustic identification of insects inspired by the speaker recognition paradigm. In Proceedings of the Ninth International Conference on Spoken Language Processing (ICSLP), Pittsburgh, PA, USA, 17-21 September 2006; pp. 2126-2129.

203. Geng, S.; Zhang, X.; Zhao, W. Detection and analysis of the stored grain insect creeping sound. Mat. Sci. Eng. 2017, $242,012093$. [CrossRef]

204. Wei, Q.; Guo, M. Detection of sound signals of two kinds of stored grain pests and their power spectrum analysis. J. Huazhong Agric. Univ. 2012, 31, 656-660.

205. Zhang, M.-Z.; Guo, M. Active acoustic signals recognition of two kinds of stored grain pests based on fastICA algorithm. J. Huazhong Univ. Sci. Technol. 2012, 31, 778-782.

206. Banga, K.S.; Kotwaliwale, N.; Mohapatra, D.; Giri, S.K.; Babu, V.B. Bioacoustic detection of Callosobruchus chinensis and Callosobruchus maculatus in bulk stored chickpea (Cicer arietinum) and green gram (Vigna radiata). Food Control 2019, 104, $278-287$. [CrossRef]

207. Ekramirad, N.; Parrish, C.A.; Villanueva, R.T.; Donohue, K.D.; Adedeji, A.A. Low frequency signal patterns for codling moth larvae activity in apples. In Proceedings of the 2020 ASABE Annual International Virtual Meeting, Omaha, NB, USA, $12-15$ July 2020. [CrossRef]

208. Schofield, J.; Chesmore, D. Automated acoustic identification of beetle larvae in imported goods using time domain analysis. J. Acoust. Soc. Am. 2008, 123, 3778. [CrossRef]

209. Görres, C.M.; Chesmore, D. Active sound production of scarab beetle larvae opens up new possibilities for species-specific pest monitoring in soils. Sci. Rep. 2019, 9, 10115. [CrossRef]

210. Kumar, S.; Mohapatra, D.; Kotwaliwale, N.; Singh, K.K. Efficacy of sensor assisted vacuum hermetic storage against chemical fumigated wheat. J. Stored Prod. Res. 2020, 88, 101740. [CrossRef]

211. Loizou, P.C.; Kim, G. Reasons why current speech-enhancement algorithms do not improve speech intelligibility and suggested solutions. IEEE Trans. Audio Speech Lang. Process. 2011, 19, 47-56. [CrossRef]

212. Guo, M.; Zhang, M. Research on acoustical signals recognition of stored grain pests based on GMM and clustering method. J. Nanjing Agric. Univ. 2012, 35, 44-48.

213. Zhang, M.; Guo, M. Research on Acoustic Signal Recognition of Stored Grain Pests Based on Manifold Learning and SVM. J. Yunnan Univ. (Nat. Sci. Ed.) 2014, 36, 174-180.

214. Lyu, Q.; Guo, M.; Ma, M.; Mankin, R. External prior learning and internal mean sparse coding for image denoising. J. Electron. Imaging 2019, 28, 033014. [CrossRef]

215. Zhu, L.; Zhang, Z. Insect sound recognition based on SBC and HMM. In Proceedings of the 2010 International Conference on Intelligent Computation Technology and Automation, Changsha, China, 11-12 May 2010; pp. 544-548.

216. Zhu, L.Q.; Zhang, Z. Automatic recognition of insect sounds using MFCC and GMM. Acta Entomol. Sin. $2012,55,466-471$.

217. Chaves, V.A.; Elizondo, C.M.; Travieso, A.C.; Alonso, J.B. Katydids acoustic classification on verification approach based on MFCC and HMM. In Proceedings of the 2012 IEEE 16th International Conference on Intelligent Engineering Systems (INES), Lisbon, Portugal, 13-15 June 2012; pp. 561-566. 
218. Phung, Q.V.; Ahmad, I.; Habibi, D.; Hinckley, S. Automated insect detection using acoustic features based on sound generated from insect activities. Acoust. Aust. 2017, 45, 445-451. [CrossRef]

219. Zamanian, H.; Pourghassem, H. Insect identification based on bioacoustic signal using spectral and temporal features. In Proceedings of the 2017 Iranian Conference on Electrical Engineering (ICEE), Tehran, Iran, 2-4 May 2017; pp. 1785-1790.

220. Nanda, M.A.; Seminar, K.B.; Nandika, D.; Maddu, A. Discriminant analysis as a tool for detecting the acoustic signals of termites Coptotermes curvignathus (Isoptera: Rhinotermitidae). Int. J. Technol. 2018, 9, 840-851. [CrossRef]

221. Fleurat-Lessard, F. Monitoring insect pest populations in grain storage: The European context. Stewart Postharvest Rev. 2011, 3 , 1-8. [CrossRef]

222. White, G.G. Population Dynamics of Tribolium castaneum (Herbst) with Implications for Control Strategies in Stored Wheat. Ph.D. Thesis, University of Queensland, Brisbane, Australia, 1985.

223. Mahmood, T.; Ahmad, M.S.; Ahmad, H. Dispersion of stored grain insect pests in a wheat-filled silo. Int. J. Pest Man. 1996, 42, 321-324. [CrossRef]

224. Perez-Mendosa, J.; Flinn, P.W.; Campbell, J.F.; Hagstrum, D.W.; Throne, J.E. Detection of stored-grain insect infestations in wheat transported in railroad hopper-cars. J. Econ. Entomol. 2004, 97, 1474-1483. [CrossRef]

225. Brabec, D.; Dowell, F.; Campbell, J.; West, M. Detection of internally infested popcorn using electrically conductive roller mills. J. Stored Prod. Res. 2017, 70, 37-43. [CrossRef]

226. Guo, M.; Ma, Y.; Wang, X.; Mankin, R.W. Detection of damaged wheat kernels using an impact acoustic signal processing technique based on Gaussian modelling and an improved extreme learning machine algorithm. Biosyst. Eng. 2019, 184, 37-44. [CrossRef]

227. Zorovic, M.; Čokl, A. Laser vibrometry as a diagnostic tool for detecting wood-boring beetle larvae. J. Pest Sci. 2015, 88, 107-112. [CrossRef]

228. Nowak, L.J.; Nowak, K.M. Perceptual audio processing stethoscope. J. Acoust. Soc. Am. 2019, 146, 1769-1773. [CrossRef]

229. Gutiérrez, A.; Ruiz, V.; Moltó, E.; Tapia, G.; Téllez, M. Development of a bioacoustic sensor for the early detection of Red Palm Weevil (Rhynchophorus ferrugineus Olivier). Crop Prot. 2010, 29, 671-676. [CrossRef]

230. Banlawe, I.A.P.; Dela Cruz, J.C. Acoustic sensors for mango pulp weevil (Stretochenus frigidus sp.) detection. In Proceedings of the 2020 IEEE 10th International Conference on System Engineering and Technology (ICSET), Shah Alam, Malaysia, 9 November 2020; pp. 191-195.

231. Ashry, I.; Mao, Y.; Al-Fehaid, Y.; Al-Shawaf, A.; Al-Bagshi, M.; Al-Brahmin, S.; Ng, T.K.; Ooi, B.S. Early detection of red palm weevil using distributed optical sensor. Sci. Rep. 2020, 10, 3155. [CrossRef] [PubMed]

232. Ku, E.M.; Duckworth, G.L. Tracking a human walker with a fiber optic distributed acoustic sensor. Proc. Meet. Acoust. $2013,19,070053$.

233. Gedeon, C.I.; Flórián, N.; Liszli, P.; Hambek-Oláh, B.; Bánszegi, O.; Schellenberger, J.; Dombos, M. An opto-electronic sensor for detecting soil microarthropods and estimating their size in field conditions. Sensors 2017, 17, 1757. [CrossRef] [PubMed]

234. Qin, Y.; Wu, Y.; Wang, Q.; Yu, S. Method for pests detecting in stored grain based on spectral residual saliency edge detection. Grain Oil Sci. Tech. 2019, 32, 33-38. [CrossRef]

235. Osbrink, W.; Cornelius, M. Utility of acoustical detection of Coptotermes formosanus (Isoptera: Rhinotermitidae). Sociobiology 2013, 60, 69-76. [CrossRef]

236. Njoroge, A.W.; Affognon, H.; Mutungi, C.; Rohde, B.; Richter, U.; Hensel, O.; Mankin, R.W. Frequency and time pattern differences in acoustic signals produced by Prostephanus truncatus (Horn) (Coleoptera: Bostrichidae) and Sitophilus zeamais (Motschulsky) (Coleoptera: Curculionidae) in stored maize. J. Stored Prod. Res. 2016, 69, 31-40. [CrossRef]

237. Njoroge, A.; Affognon, H.; Richter, U.; Hensel, O.; Rohde, B.; Chen, D.; Mankin, R. Acoustic, pitfall-trap, and visual surveys of stored product insect pests in Kenyan warehouses. Insects 2019, 10, 105. [CrossRef] [PubMed]

238. Eliopoulos, P.; Tatlas, N.-A.; Rigakis, I.; Potamitis, I. A "smart" trap device for detection of crawling insects and other arthropods in urban environments. Electronics 2018, 7, 161. [CrossRef]

239. Rigakis, I.; Potamitis, I.; Tatlas, N.A.; Potirakis, S.M.; Ntalampiras, S. TreeVibes: Modern tools for global monitoring of trees against borers. Automot. Eng. 2021, 4, 271-284. [CrossRef]

240. Koubaa, A.; Aldawood, A.; Saeed, B.; Hadid, A.; Ahmed, M.; Saad, A.; Alkhouja, H.; Ammar, A. Smart Palm: An IoT framework for red palm weevil early detection. Agronomy 2020, 10, 987. [CrossRef]

241. Mousavi, S.F.; Abbaspour Fard, M.H.; Aghkani, M.H.; Namaghi, H.S.; Ebrahimi, E. Acoustic detection possibility of different stages of the confused flour beetle (Tribolium confusum) using an audio sensor. J. Agric. Sci. Tech. 2017, 19, 1551-1563.

242. Krajewski, A.; Witomski, P.; Bobiński, P.; Wójcik, A.; Nowakowska, M. An attempt to detect fully-grown house longhorn beetle larvae in coniferous wood based on electroacoustic signals. Drew. Pr. Nauk. Donies. Komun. 2012, 55, 5-15.

243. Fleming, M.R.; Bhardwaj, M.C.; Janowiak, J.J.; Shield, J.E.; Roy, R.; Agrawal, D.K.; Bauer, L.S.; Miller, D.L.; Hoover, K. Noncontact ultrasound detection of exotic insects in wood packing materials. For. Prod. J. 2005, 55, 33-37.

244. Evans, T.A. Assessing efficacy of Termatrac (TM): A new microwave based technology for non-destructive detection of termites (Isoptera). Sociobiology 2002, 40, 575-583.

245. Taravati, S. Evaluation of low-energy microwaves technology (Termatrac) for detecting Western drywood termite in a simulated drywall System. J. Econ. Ent. 2018, 111, 1323-1329. [CrossRef]

246. Reimer, A.; Wiebe, K.; Rao, J.; Yao, B.; Gui, Y.; Jian, F.; Fields, P.; Jayas, D.S.; Hu, C.-M. A compact microwave device for monitoring insect activity in grain samples. Biosyst. Eng. 2018, 175, 27-35. [CrossRef] 
247. Solà, M.; Riudavets, J.; Agustí, N. Detection and identification of five common internal grain insect pests by multiplex PCR. Food Control 2018, 84, 246-254. [CrossRef]

248. Liang, S.; Wang, X.; Wiedenbeck, J.; Cai, Z.; Fu, F. Evaluation of acoustic tomography for tree decay detection. In Proceedings of the 15th International Symposium on Nondestructive Testing of Wood, Duluth, MN, USA, 10-12 September 2007; pp. 49-54.

249. Fiala, P.; Friedl, M.; Cap, M.; Konas, P.; Smira, P.; Naswettrova, A. Nondestructive method for detection wood-destroying insects. In Proceedings of the Progress in Electromagnetics Research Symposium, Guangzhou, China, 25-28 August 2014; pp. 1642-1646.

250. Eliopoulos, P.A.; Givropoulou, E.G.; Potamitis, I.; Kontodimas, D.C. Detection of insect infestation in stored wheat based on their acoustic emissions. IOBC WPRS Bull. 2014, 98, 66.

251. Guo, M.; Shang, Z. A new method of detection of pests in agricultural products by acoustical signals detection. J. Shaanxi Norm. Univ. (Nat. Sci. Ed.) 2001, 29, 107-112.

252. Guo, M.; Shang, Z. Detection and application of acoustic signals of stored grain pests. Physics 2001, 30, 39-42.

253. Geng, S.; Shang, Z. Research progress and prospects of stored grain insect sound detection technology. Trans. Chin. Soc. Agric. Eng. 2006, 22, 204-207.

254. Wei, X.; Xuguang, B.; Daoyin, Q. Detection methods of stored grain pests at home and abroad. Grain Oil Warehous. Technol. News 2001, 5, 41-43.

255. Qiu, D.Y.; Zhang, C.H.; Zhang, H.T.; Shen, X.Z.; Yue, Y.J. Application of neural network in the identification of stored grain pests. Trans. CSAE 2003, 19, 142-144.

256. Hu, L.; Guo, M.; Zhang, J.; Ren, N. New detection technology and application status of stored-grain insects. Trans. Chin. Soc. Agric. Eng. 2007, 23, 286-290.

257. Liao, M. Design of sound analysis system for stored grain injurious insect. J. Chi. Cereals Oils Assoc. 2007, 22, 130-134.

258. Wei, X.; Wen, J.; Zhao, Y.; Xu, Z. Review on monitoring technology of the insect acoustic. Sci. Silvae Sin. 2010, 46, 147-154.

259. Guo, M.; Zhang, L. Research and development of detection methods for stored grain pests based on acoustic signals. J. Chi. Cereals Oils Assoc. 2011, 26, 123-128.

260. Zhen, T.; Dong, Z.; Guo, J.; Sang, J.; Wu, J. Sound-based stored grain pest detection system. J. Henan Univ. Tech. (Nat. Sci. Ed.) 2012, 33, 79-82.

261. Jie, P.; Yulin, A.; Xiang, L.; Peize, S.; Liusong, Y.; Guoxun, Q.; Lianyungang, W.J. Entry-exit inspection, quarantine bureau, and Jiangsu entry-exit inspection. The application and prospect of sound monitoring in log quarantine. Plant Quar. 2013, 5, 17-20.

262. Zhu, Y.; Li, M.; Dang, H.; Zhen, T. Research status and prospects of stored grain pest detection and identification technology. J. Henan Univ. Technol. (Nat. Sci. Ed.) 2015, 36, 102-106.

263. Gao, H.; Zhen, T.; Zhu, Y. Present situation and prospects of detection technology of stored-grain insects. Grain Storage 2015, $44,10-14$.

264. Gao, H.; Zhu, Y.; Zhēn, T. Present situation and prospects of detection technology of stored-grain insect. Grain Oil Food Tech. 2016, $24,93-96$.

265. Geng, S.; Li, F. Sound propagation characteristic in grain with large kernel. J. Yunnan Univ. (Nat. Sci. Ed.) 2008, 6, 11.

266. Guo, M. Propagation of Sound Signals in Quasi-Porous Media and Analyze the Sound Properties of Pests. Ph.D. Thesis, Shaanxi Normal University, Xi'an, China, 2003.

267. Guo, M.; Shang, Z.; Shi, H. Study on acoustic absorption of various grains. J. Northwest Univ. Nat. Sci. 2004, 34, 34-38.

268. Yan, H.; Chen, G.; Zhou, Y.; Liu, L. Experimental study of sound travel time estimation method in stored grain. J. Comput. 2012, 7, 947-953. [CrossRef]

269. Yu, P.; Yan, H.; Yao, L. Measurement of acoustic attenuation coefficient of stored grain. In Proceedings of the 2017 3rd International Conference on Control, Automation and Robotics (ICCAR), Nagoya, Japan, 24-26 April 2017; pp. 551-554.

270. Sakai, H.; Minamisawa, A.; Takagi, K. Effect of moisture content on ultrasonic velocity and attenuation in woods. Ultrasonics 1990, 28, 382-385. [CrossRef]

271. Wassilieff, C. Sound absorption of wood-based materials. Appl. Acoust. 1996, 48, 339-356. [CrossRef]

272. Gao, S.; Xiping, W.; Wang, L.; Allison, R.B. Modeling temperature and moisture state effects on acoustic velocity in wood. In Proceedings of the 17th International Symposium on Nondestructive Testing and Evaluation of Wood, Sopron, Hungary, 14-16 September 2011; pp. 411-418.

273. Unterwieser, H.; Schickhofer, G. Influence of moisture content of wood on sound velocity and dynamic MOE of natural frequencyand ultrasonic runtime measurement. Eur. J. Wood Prod. 2011, 69, 171-181. [CrossRef]

274. Charif, R.A.; Waack, A.M.; Strickman, L.M. Raven Pro 1.3 User's Manual; Cornell Laboratory of Ornithology: Ithaca, NY, USA, 2008.

275. Perles, A.; Mercado, R.; Capella, J.; Serrano, J. Ultra-Low power optical sensor for xylophagous insect detection in wood. Sensors 2016, 16, 1977. [CrossRef]

276. Flynn, T.; Masters, H.; Hull-Sanders, H.; Salloum, H.; Sedunov, A.; Sedunov, N.; Sutin, A. Autonomous detection of Trogoderma inclusum in grain. In Proceedings of the 27th USDA Interagency Research Forum on Invasive Species, Annapolis, MD, USA, 12-15 January 2015; McManus, K.A., Ed.; USDA Forest Service: Washington, DC, USA, 2016; pp. 9-12.

277. Gerken, A.R.; Campbell, J.F. Life history changes in Trogoderma variabile and T. inclusum due to mating delay with implications for mating disruption as a management tactic. Ecol. Evol. 2018, 8, 2428-2439. [CrossRef] [PubMed]

278. Farr, I. Automated Bioacoustic Identification of Statutory Quarantined Insect Pests. Ph.D. Thesis, University of York, York, UK, 2007.

279. Geng, S. Sound Characteristics Detection, Analysis and Database Construction of Stored Grain Pests. Ph.D. Thesis, Shaanxi Normal University, Xi'an, China, 2005. 
280. Kiobia, D.O. Design and Development of a Low-Cost Acoustic Device to Detect Pest Infestation in Stored Maize. Master's Thesis, Virginia Polytechnic Institute and State University, Blacksburg, VA, USA, 2015.

281. Klaassen, R.E. Identification of Concealed Insect Infestations Using a Passive Ultrasound Monitor. Master's Thesis, Purdue University, West Lafayette, IN, USA, 1989.

282. Njoroge, A.W. Acoustic Detection of Insect Pests of Stored Grains in Kenya. Ph.D. Thesis, Universität Kassel, Kassel, Germany, 2017.

283. Pesho, G.R. Detection of Immature Rice Weevils, Sitophilus oryzae L. (Curculionidae, Coleoptera), by Audio Amplification. Master's Thesis, Kansas State College of Agriculture and Applied Science, Manhattan, KS, USA, 1954.

284. Rigato, F.E. Indagini Bioacustiche per l'Identificazione di Larve di Coleotteri Cerambicidi (Coleoptera Cerambycidae). Master's Thesis, University of Padua, Padua, Italy, 2013.

285. Schofield, J. Real-Time Acoustic Identification of Invasive Wood-Boring Beetles. Ph.D. Thesis, University York, York, UK, 2011.

286. Desjonquères, C.; Rybak, F.; Ulloa, J.S.; Kempf, A.; Hen, A.B.; Sueur, J. Monitoring the acoustic activity of an aquatic insect population in relation to temperature, vegetation, and noise. Freshw. Biol. 2018, 65, 1. [CrossRef]

287. Hubert, J.; Stejskal, V.; Athanassiou, C.G.; Throne, J.E. Health hazards associated with arthropod infestation of stored products. Annu. Rev. Entomol. 2018, 63, 553-573. [CrossRef] [PubMed]

288. Zhai, Z.; Martínez, J.F.; Beltran, V.; Martínez, N.L. Decision support systems for agriculture 4.0: Surveys and challenges. Comp. Electron. Agric. 2020, 170, 105256. [CrossRef]

289. Montgomery, G.A.; Belitz, M.W.; Guralnick, R.P.; Tingley, M.W. Standards and best practices for monitoring and benchmarking insects. Front. Ecol. Evol. 2021, 8, 579193. [CrossRef]

290. Vincent, C.; Weintraub, P.G.; Hallman, G.J.; Fleurat-Lessard, F. Insect management with physical methods in pre- and post-harvest situations. In Integrated Pest Management; Radcliff, E.B., Hutchison, W.D., Cancelado, R.E., Eds.; Cambridge University Press: Cambridge, UK, 2009; pp. 309-323. 